\title{
V. A Revised Catalogue of the Lucanoid Coleoptera; with Remarks on the Nomenclature, and Descrip- tions of New Species.
}

By Major F. J. Sidney Parry, F.L.S., V.-P. Ent. Soc.

[Read 7th June, 1869, and 7th February, 1870.]

Since the publication, nearly six years ago, in the Society's Transactions (third series, vol. ii. p. 1) of my Catalogue of this interesting group, fresh material has become available for correcting certain errors contained therein, and affords the opportunity of offering a few remarks upon those new species which have up to the present period fallen under my notice, and of recording those changes which it now appears to me expedient to carry out.

Certain of these proposed alterations, especially in the nomenclature of species, have already been recently published by Dr. Gemminger and Baron E. von Harold (Catalogus Coleopterorum, vol. iii, 1859), to whom I had much pleasure in imparting such information as was in my power to offer. I think, however, that a fuller statement, and more diffuse remarks respecting these alterations, will not be inappropriate; leading, as I trust they may hereafter, to more valuable results in regard to the systematic arrangement, both of genera and species.

It may be advantageous briefly to particularise the statistical differences existing between my publication in 1864, and the "Catalogus Coleopterorum," for the production of which Entomologists are much indebted; I think, however, it is to be regretted, that the alphabetical arrangement of species was adopted; and moreover, a concentration of genera has in some instances been made, which is not in my opinion quite warranted.

The following is a list of thirty-three names, not included as species in my former Catalogue, which are enumerated by Gemminger and Von Harold as distinct; and of seven species included in my former Catalogue, but considered by them as synonyms.

1. Lamprima cultridens, Burm.

\begin{tabular}{lr|ll} 
2. & " nigricollis, Hope. & 5. & Odontolabis Duivenbodei, Deyr \\
3. Streptocerus eustictus, Philippi. & 6. & " & gracilis, Kaup.
\end{tabular}

4. Lucanus curtulus, Motsch.

TRANS. ENT. SOC. 1870.-PART I. (MARCH.) 
7. Odontolabis inaqualis, Kaup.

8. ", Swinhoei, Bates.

9. Neolucanus lama, Oliv.

10. Cladognathus Batesi, Parry.

11. ,, dentifer, Deyr.

12. " Lorquini, Deyr.

13. ,, Motschulskyi,

14. , vittatus, Deyr.

15. Cyclophthalmus Kaupi, Deyr.

16. Dorcus Alcides, Voll.

17. ", Castelnaui, Deyr.

18. ,, costatus, Lec.

19. ", eurycephalus, Burm.

20. " punctatostriatus, Redt.

21. , rubrofemoratus, Voll.

22. Gnaphaloryx miles, Voll.

23. Egus amictus, Deyr.

24. " Formosa, Bates.

25. , gracilis, Deyr.
26. Egus ogivus, Deyr.

27. , phitippinensis, Deyr.

28. Sclerognathus Spinola, Solier.

29. Nigidius formosanus, Bates.

30. ,, Parryi, Bates.

31. Amneidus Godefroyi, Coq.

32. Ceratognathus alboguttatus,

33.

Bates.

川

sexpustulatus,

Bates.

\section{Synonyms.}

1. Lamprima varians, Burm.

2. Lucanus turcicus, Sturm.

3. , Hopei, Parry.

4. ,, sericans, Voll.

5. Hexarthrius Chaudoiri, Deyr.

6. Platycerusoregonensis, Westw.

7. Lissotes curvicornis, Boisd.

I proceed to make a few remarks upon each of the forty above-mentioned.

\section{Lamprima cultridens, Burm.}

Upon again carefully reading Dr. Burmeister's description, and examining numerous specimens of $L$. Micardi, the above cannot, I think, be considered as distinct, and I must adhere to my already expressed opinion, that it is only a variety of $L$. Micardi.

\section{Lamprima varians, Burm.}

This species has been united by Gemminger and Von Harold with $L$. Micardi, but evidently in error, although it is very similar in general appearance. $L$. varians belongs to the first section of the genus, characterized, as "calcare maris antico late trigono," whereas $L$. Micardi belongs to the second section, "calcare maris antico angusto." In my former publication $L$. varians was inadvertently placed in the second section.

\section{Lamprima nigricollis, Hope.}

This insect is not included among the six species of the genus recorded by Mr. Hope in his Catalogue of Lucanidae (p. 1.), but the description is given at p. 28 . 
In my former publication this appears to have escaped my notice, as I did not allude to it. Dr. Burmeister's description of $L$. Micardi so readily answers to the above, that it appeared to me evident that the two were identical; and having recently had the opportunity of examining the type specimen of nigricollis in the Hopeian Museum at Oxford, this opinion has been fully confirmed.

\section{Streptocerus eustictus.}

Philippi, Stett. Ent. Zeit. 1864, p. 316.

I am acquainted by description only with this second species of the genus Streptocerus. In Count Mniszech's collection, there exists a species under the name of $S$. nitidipennis, which probably may prove identical with the above.

\section{Lucanus curtulus.}

Motsch. Bull. Mosc. 1845, p. 60.

The difficulty of recognizing this as a distinct species appears to be considerable, seeing the diversity of opinion expressed by several entomologists, in reference to it and other allied insects, namely, $L$. orientalis, Kraatz, L. ibericus, Motsch., and L. tetraodon, Thunb.

Kraatz, in his elaborate paper on the European species of Lucanidae (Berl. Ent. Zeit. 1860), establishes the new species $L$. orientalis, including therewith L. ibericus?, and $L$. curtulus?. Reiche places $L$. ibericus with $L$. tetraodon; and Burmeister locates both ibericus and curtulus with $L$. Barbarossa, Fab. (This most certainly appears to be erroneous). Gemminger and Von Harold have added considerably to the confusion by having first recognized $L$. curtulus as distinct, and then suppressed $L$. orientalis as identical with $L$. ibericus. But for the present, I do not deem it advisable to alter the arrangement made in my former Catalogue.

\section{Lucanus turcicus, Sturm.}

Gemminger and Von Harold give this as a synonym of $L$. cervus, agreeing in this respect with Kraatz (Stett. 
Ent. Zeit. 1860, p. 273), but differing from Lacordaire and Reiche. Under these circumstances, I feel disposed to maintain it for the present as a distinct species.

\section{Lucanus Hopei, Parry. \\ Lucanus sericans, Voll.}

These two have been satisfactorily shown to be identical with $L$. maculifemoratus, which has priority of publication. In my former Catalogue allusion was made to the affinity between $L$. sericans and Hopei, but $L$. maculifemoratus was therein mentioned as distinct.

\section{Hexarthrius Chaudoiri.}

Deyr. Ann. Soc. Ent. Fr. 1864, p. 312, pl. iv. fig. 1.

Whether this insect from Sumatra is to be considered as distinct, or only as a geographical variety of $H$. rhinoceros, from Java, is, perhaps, somewhat questionable. Mons. H. Deyrolle in his description, alludes to the close alliance between the two. In my former Catalogue, H. Chaudoiri, then unpublished, was noticed upon Mons. Deyrolle's authority; but from his now published description, I feel inclined to believe that it represents only a geographical variety; in this view I am supported by Mons. Snellen van Vollenhoven, (Tijd. v. Ent. 1865, p. 148), who states, that the Leyden Museum possesses several individuals from Sumatra, not quite agreeing with $H$. Chaudoiri, but forming the passage between that and $H$. rhinoceros.

\section{Odontolabis Duivenbodei.}

Deyr. Ann. Soc. Ent. Belg. 1865, p. 25, pl. i. fig. 1 (ठ̋).

This magnificent new species, stated by the author to be allied to O. Stevensii, was discovered in the Island of Celebes, and is unique, I believe, in the collection of Count Mniszech. I may add, that according to a communication recently received from Mons. Snellen van Vollenhoven, the true habitat of $O$. Stevensii is the Sangir Islands, situate near the extreme northern point of Celebes. 
Odontolabis gracilis, Kaup.

Odontolabis incequalis, Kaup.

These two insects, described by Dr. Kaup (Col. Heft. iv. 7, 1868) as new species, were captured by Herr v. Rosenberg in the Island of Nias, situate on the Western Coast of Sumatra, and are stated by the author to be allied, the first to $O$. dux, Westwood, and O. bellicosus, Laporte; the second to O. Stevensii, Thomson, and $O$. Dejeanii, Reiche. Dr. Kaup having kindly added to my collection specimens of both insects, I am in a position to state, that 0 . gracilis must be considered as the var. max. of 0 . bellicosus, having fully developed mandibles (this being the only instance of such development which has hitherto fallen under my notice), and that $O$. inaqualis must be referred to $O$. bicolor, Olivier, of which it appears to be a singular geographical variety, having. the coloration on the elytra of a very dark chesnut, whereas in $O$. bicolor it is of a pale fulvous; in all other respects, however, the two insects appear to assimilate. Upon submitting my views with regard to the species in question to Dr. Kaup, on his late visit to England, he unhesitatingly coincided with my opinion.

\section{Neolucanus Swinhoei.}

Bates, Proc. Zool. Soc. 1866, p. 346, fig.

An interesting addition to the genus Neolucanus, discovered by Mr. Swinhoe in the island of Formosa, and described by Mr. H. W. Bates (loc. cit.) with other interesting new species. Gemminger and von Harold locate it in Odontolabis, but it is evidently more appropriately placed in Neolucanus, the mandibles of which seldom exceed the length of the head, and are arcuate, and in the species pertaining to the first section are (in the var. max.) armed with either one or two strong suberect teeth placed near the apex. Although closely resembling $N$. castanmpterus from Northern India, the author in his deseription points out the various differences; and the sub-erect tooth near the apex of the mandibles of N. Swinhoei appears to be entirely wanting in the numerous specimens of $N$. castanopterus which have fallen under my notice. 


\section{Neolucanus lama, Oliv.}

Having on a former occasion (Trans. Ent. Soc. ser. 3, i. 43) expressed an opinion as to the identity of Olivier's insect with that described by Mr. Hope, in Trans. Linn. Soc. xix. 105, under the name of Odontolabis Baladeva, and of which $O$. angulatus, subsequently described by the same author, in his Catalogue of the Lucanidae, must be considered as the var. min., I cannot concur with Gemminger and von Harold in retaining the two insects as specifically distinct; and upon again examining Olivier's description and figure, I feel convinced that the short curved form of the mandibles exhibited in pl. iii. fig. 8, renders it impossible to refer this figure to the male, in which sex the mandibles are described by Mr. Hope as being porrect and arcuate. I therefore suppress Hope's name in favour of Olivier's.

\section{Cladognathus Batesi.}

In Gemminger and Von Harold's " Catalogus" this species, from North India, has been recorded as having been or as being about to be described by myself, whereas it has been described by Mr. C. O. Waterhouse, who has created a new genus for it, and has recorded the insect as Aulacostethus Archeri (Trans. Ent. Soc. 1869, p. 14). With reference to the "prophetic utterances" note of our excellent Secretary (l.c.), the fault cannot be attributed to Gemminger and Von Harold. Mr. C. O. Waterhouse, on showing me this interesting new species, suggested that I should describe it in my present publication, (which I then hoped to have ready in 1869), and it was accordingly included in the list of new species which I sent to the Baron von Harold, under the name of Cladognathus Batesi. It was afterwards suggested that the species might appropriately be named in honour of Mr. Archer, by whom it was presented to the British Museum; but unfortunately the notice of this alteration was too late for the "Catalogus Coleopterorum."

\section{Cladognathus dentifer.}

Deyr. Ann. Soc. Ent. Belg. 1865, p. 29, pl. i. fig. 5 .

This new East Indian species, from the collection of Count Mniszech, is most probably a var. minor, and the 
author considers it should be located near $C$. Spencii, $C$. bulbosus, and $C$. crenicollis; he points out, however, the essential difference in the character of the mandibles.

\section{Cladognathus Lorquinii.}

Deyr. Ann. Soc. Ent. Belg. 1865, p. 26, pl. i. fig. 2.

This species from Celebes (Menado) is allied to C. lateralis, Hope, but the author describes it as being abundantly distinct, not only in form, but also in the disposal of its coloration. Both the $\sigma$ and $q$ are, I believe, in Count Mniszech's collection.

\section{Cladognathus Motschulskii.}

C. O. Waterh., Trans. Ent. Soc. 1869, p. 14.

The error already mentioned under Cladognathus Batesi arose also with regard to this new species from Japan.

\section{Cladognathus vittatus.}

Deyr. Ann. Soc. Ent. Belg. 1865, p. 28, pl. i. fig. 4.

Several specimens of this species from the Philippine Islands were brought to this country by the late Mr. Hugh Cuming; it has hitherto been considered a variety of $C$. lateralis, Hope. Mr. Hope and Dr. Burmeister do not appear to have noticed it in their respective publications, although, probably well acquainted with it. The two species are evidently closely allied. Mons. H. Deyrolle however, in his description, points out various differences.

Cyclophthalmus Kaupi, G. \& H. Cat. Col. iii. 953. Cyclommatus Kaupii, Deyr. Ann. Soc. Ent. Belg. 1865, p. 30 , pl. ii. fig. 2.

This new species, dedicated by the author to Dr. Kaup of Darmstadt, is from the island of Celebes.

We have here an instance of the great inconvenience arising from the unsettled state of the nomenclature of genera. My attention has been called to this subject, by the restitution of Mr. Hope's name. Cyclophthalmus; this appropriate designation was recorded both by Dr. Burmeister and Professor Lacordaire in their respective 
publications, but Mr. Thomson in his "Catalogue des Lucanides," stating the name to have been already preoccupied by Sternberg for a genus of Arachnida, substituted Megaloprepes for Cyclophthalmus; upon the same principle I was forced (Tr. Ent. Soc. 3rd series, i. 9) again to alter the name, and proposed Cyclommatus. Gemminger and Von Harold appear once more to have decided in favour of Mr. Hope's name, perhaps through an oversight. I must again express my opinion, that no great inconvenience can arise from the double employment of a name when it does not occur in the same Order; although such employment should, of course, as far as practicable be avoided.

Dorcus Alcides, G. \& H. Cat. Col. iii. 956.

Eurytrachelus Alcides, Voll. Tijd. Ent. 1865, p. 150, pl. x. fig. 2 ๙ , 3 q.

This is from Sumatra. From the excellent figures of the $\delta$ and $q$ accompanying the description of this new species, and looking at the character of the internal armature of the mandibles, the form of the clypeus, together with that of the sides of the prothorax, I am inclined to place it near Eurytrachelus ceramensis and concolor; the fore-tibiæ (in the figure) are clothed internally with a strong golden pubescence, a character which I do not remark in other species of this genus.

Gemminger and Von Harold appear to have included in Dorcus several distinct genera; and as regards the reference to “Metopodontus (pars) Hope," I cannot, among the forty-three species of Dorcus recorded, detect a single one which belongs to Metopodontus.

Dorcus Castelnaui, G. \& H. Cat. Col. iii. 956.

Eurytrachelus Castelnaudii, Deyr. Ann. Soc. Ent. Belg. 1865, p. 31, pl. ii. fig. 3.

This new species from Bengal is in the collection of Count Mniszech. Mons. Henri Deyrolle states it to be allied to a medium development of E. Reichei, Hope; he further maintains in a note, that Castelnaudii is orthographically correct. The $q$ is not known. 
Dorcus costatus.

Leconte, Proc. Ac. Philad. 1866, p. 380.

This species is stated to be only an extreme var. $q$ of D. parallelus (see Coleopt. United States List, add. 1867).

\section{Dorcus eurycephalus, Burm.}

When my former Catalogue was published, but little information was available for the exact determination of this species of Dr. Burmeister (Handb. v. 387) ; accordingly, I then followed in the footsteps of Mons. Reiche and Professor Lacordaire, by placing it as a synonym of $E$. bubalus, Perty, notifying at the same time the possibility of its being distinct. This view has now proved to be correct, according to Mons. v. Vollenhoven, who (in the Tijd. v. Ent. 1865, p. 151) has described a specimen from the Leyden Museum. I have recently seen another specimen in the Berlin Museum, corresponding with the figure given, and having Dr. Burmeister's name attached; possibly it may be the type specimen. $E$. eurycephalus appears to be allied to E. Saiga and E. purpurascens, differing considerably in the form of the clypeus, as well as in many other respects pointed out by the author; with E. Saiga and E. purpurascens, this makes the third species of the genus which has the interior of the mandibles partially clothed with silken pubescence.

\section{Dorcus punctatostriatus, Redt.}

The author, in his notice of this insect, alludes to the probability of its being identical with $D$. lineatopunctatus, Hope, Zool. Misc. p. 22, a species recorded in my former publication as being the $q$ of Eurytrachelus Tityus. The description of the two insects corresponds so entirely, that I have little hesitation in adhering to my former opinion, that $D$. punctatostriatus cannot be considered as a distinct species, but be referred to $D$. lineatopunctatus.

Dorcus rubrofemoratus, G. \& H. Cat. Col. iii. 958.

Eurytrachelus rubrofemoratus, Vollenh. Tijd. Ent. 1865, p. 152, pl. xi. fig. 1, 2, ठ, ㅇ.

This new species, discovered by Siebold and Burger, in Japan, ought to be located near Eurytrache- 
lus niponensis, Voll., which it resembles in general character, but differs more particularly by the internal armature of the mandibles, consisting of three teeth irregularly placed near their apex; and by the femora being partially of a bright rufous colour. The $\delta$ specimen with which Mons. v. Vollenhoven was kind enough to enrich my collection, represents, I think, a var. max. It is very possible that hereafter both species may prove to belong to the genus Macrodorcas, of Motschulsky; that author described five species in "Etudes Entomologiques," all from Japan, but at present I am totally unacquainted with any of them.

\section{Gnaphaloryx miles.}

Vollenh. Tijd. Ent. 1865, p. 155, pl. xi. fig. 5 ( ๙

I am indebted to M. Snellen van Vollenhoven for a specimen of this remarkable new species, discovered by Mr. Bernstein, and indigenous to Halmaheira and Gebeh; in an elaborate description of both $\delta$ and $q$, the author alludes to the extraordinary cephalic horn as being peculiar to this species alone among the Lucanoid Coleoptera; this, however, is a slight error, as the same character is exhibited in a species of Ceratognathus from New Holland, described by Professor Westwood, under the name of $C$. mentiferus.

Agus philippinensis.

Agus ogivus.

Agus gracilis.

Agus amictus.

Deyr. Ann. Soc. Ent. Belg. 1865, pp. 32-35, pl. ii. fig. 4-7.

These four species have been described and figured by Mons. H. Deyrolle, and although closely allied to others already well-known, they exhibit according to the author's descriptions various material differences. AEgus philippinensis and ogivus are both mentioned as allied to $A$. acuminatus, Fabr.; E. gracilis to A. serratus, Parry; and A. amictus, a small species, to A. Myrmidon and adelphus, Thomson. 


\section{Aggus Formosce.}

Bates, Proc. Zool. Soc. 1866, p. 347.

Several specimens, with various gradations of form, were received by Mr. Bates, and having had the opportunity of examining a numerous series, I am able to coincide with the author in his view as to their close affinity to Agrus lcevicollis, Saunders (from China), of which species AE. Formosce may perhaps be considered only as a geographical variety. The punctuation, however, as exhibited both above and below in the female, appears to be considerably coarser and stronger in $\mathbb{E}$. Formosce than in A. lavicollis. The var. max. of exhibits a nodose tubercle on the head adjacent to the base of each mandible, which in the var. med. is but rudimentary, and in specimens of the var. min. is entirely wanting ; the same will, I have no doubt, prove to be the case with A. levicollis, but I am not acquainted with the var. max. of the latter species.

\section{Platycerus oregonensis, Westw.}

This insect described by Professor Westwood (Tr. Ent. Soc. iv. 277) and alluded to as being probably identical with $P$. quercus (a well-known species from North America), has been located as such by Gemminger and Von Harold. In my former Catalogue it was noticed as being a doubtful species. Dr. Leconte in his " List of Coleoptera of North America" (published 1863-1866) does not appear to consider $P$. oregonensis as a distinct species, but refers it (with doubt, however) to Platycerus depressus; in this however, I do not feel disposed to agree, considering it, from description, to be more closely allied to $P$. quercus.

\section{Sclerognathus Spinolce, Solier.}

In this case, Gemminger and Von Harold appear somewhat inconsiderately to have changed the generic name Sclerostomus, Burmeister, to Sclerognathus (Burm. MS.), Hope, Cat. Luc. 1845. Dr. Burmeister in establishing the genus Sclerostomus in his "Handbuch der Entomologie," 1847, p. 423 , states that at the period he proposed the name of Sclerognathus it had not been employed, but that in the interim it had been used by Mons. Valenciennes to designate a group of fishes. 
With regard to S. Spinolce, originally described in Gay's Hist. Chili, Gemminger and Von Harold are correct in assuming it to be distinct; it very closely resembles the var. minor of S. femoralis, Guérin, to which species (for want of a knowledge of other specimens than the one in my own collection, which is somewhat mutilated) I had in my former Catalogue assigned it; but I have recently seen other specimens, in the collections of the Jardin des Plantes and of Count Mniszech, received from Mons. Solier, and I agree that the species is distinct.

\section{Lissotes curvicornis, Boisd.}

As Gemminger and Von Harold have erroneously placed $L$. curvicornis as a synonym of $L$. cancroides, Fabr., it may be advisable to offer the following observations in reference to the two insects, more especially as in many collections they are noted as being identical; indeed it was not until recently, upon obtaining a knowledge of the type specimens, that my own doubts on the subject have been removed.

Dorcus curvicornis was recorded in Count Dejean's Catalogue, but whether identical with the insect described by Boisduval (Voy. de l'Astrol. p. 235) I am not in a position to affirm. Dr. Burmeister (Handb. v. 402) refers curvicornis, Dej., to Agus obtusatus, Westw., but this is evidently incorrect. Having recently examined the type specimen of $L$. curvicornis in the Museum at the Jardin des Plantes, which was received from Dr. Boisduval, I feel satisfied of its being perfectly distinct from any of the allied species, L. cancroides, Fab., L. tubercutus, Westw., and L. obtusatus, Westw., with one or other of which it appears to have been frequently confounded; indeed, Prof. Westwood has recently received from Dr. Howitt of Melbourne, specimens both $\delta$ and $q$ of $L$. curvicornis, Boisd., under the name L. cancroides, Fab., Dr. Howitt stating in his letter that the insect sent as $L$. cancroides appeared to him to be identical with $L$. curvicornis, grounding his opinion on an insect he had seen so labelled in Count de Castelnau's collection. This view proves to be correct, upon comparison of the type specimen with the insect sent to Prof. Westwood, who will shortly publish descriptions of some interesting new species of the genus Lissotes, and will probably give a more minute description of $L$. curvicornis than that in the "Voyage de l'Astrolabe." Upon the present 
occasion, I will merely refer, as distinguishing it from other allied species, to the punctuation, which is much less defined, to the form of the prothorax, which is wider and more depressed, with the anterior angles more rounded, and the posterior more emarginate, and finally to the total absence of the minute central tubercle of its anterior margin, as exhibited in $L$. cancroides and $L$. tuberculatus.

With regard to $L$. cancroides of Fab. and Oliv., the type specimen is in the British Museum (Banksian Collection) and of this Prof. Westwood published a full description accompanied by a figure (Ent. Mag. v. 267) ; this species is unquestionably very closely allied to $L$. subtuberculatus, Westw. (Tr. Ent. Soc., n. s., iii. 216, pl. xii. f. 2), and to this the author himself alludes; but upon a rigid comparison of the two insects, I find that L. cancroides is narrower and longer, with the punctuation, especially on the head and prothorax, considerably sparser, the latter with the posterior angles less emarginate, the small tubercle of the centre of the anterior margin simple, instead of being slightly bifid as in $L$. tuberculatus, the head somewhat broader, and less excavated in front, with the base of the mandibles internally slightly more emarginate. Whether these characters will prove to be constant in a long series of specimens I cannot conjecture ; for the present, at all events, it may be advisable, to maintain $L$. subtuberculatus as a distinct species. Dr. Boisduval, referring both to Fabricius and Olivier, with a brief description, gives the habitat of $\mathrm{New}$ Guinea; there must, I think, be some error, either as to identity of species or as to the habitat; in describing the prothorax, he says, "thorace transverso, angulis posticis obliquis, punctis crebris, foveolisque duabus impressis;" this latter character is certainly not to be found in the type specimen, still less does New Guinea accord with its habitat, which I believe unquestionably to be New Holland; I am at a loss to conceive, therefore, to what species Boisduval's insect is to be referred.

\section{Nigidius formosanus.}

Bates, Proc. Zool. Soc. 1866, p. 347.

This new species, from the Island of Formosa, comes nearest to $N$. loevicollis, on comparing it with specimens of the same development: but it is evidently distinct, its general appearance being considerably less shining, and 
the punctuation of the thorax is of a totally different character, being much more diffuse, and sparsely scattered over the entire surface, whereas in N. lavicollis, it is close, and confined entirely to the sides; moreover, the punctuation of the striæ in the interstices of the sulcate elytra is much less apparent. An unique specimen is in the collection of $\mathrm{Mr}$. Bates.

\section{Nigidius Parryi.}

Bates, Proc. Zool. Soc. 1866, p. 347.

The largest species of Nigidius (?) with which I am acquainted, measuring 13 lines ; it forms a most interesting link between Nigidius and Figulus, assimilating perhaps more to the latter than to the former. The sub-erect tooth, invariably exhibited on the mandibles of the several species of Nigidius, is in the present instance wanting; the character of the mandibles resembles those of Figulus, being porrect, recurved near the apex, excavated interiorly and strongly rugose-punctate; the sides of the head before the eyes are rounded, and not angulate, as is usual in Nigidius; the sides of the thorax are, however, similar, being emarginate, and the anterior margin is furnished with a small obtuse spine in its centre; the body varies also in character, being considerably more depressed and more elongate. Were it not for the character exhibited in the sides of the thorax, which is so peculiar to the genus Nigidius, there could be no hesitation in placing this species in the genus Figulus; for the present, however, it may, perhaps, be located with Nigidius, sectionally forming the passage to Figulus. This unique specimen from Formosa is in the collection of Mr. Bates, and was collected with other interesting specimens by $R$. Swinhoe, Esq., H. B. M. Consul at that island.

\section{Amneidus Godefroyi.}

Coquerel, Ann. Soc. Ent. Fr. 1866, p. 326, pl. vii.

$$
\text { fig. } 1(\delta, q) \text {. }
$$

This new and interesting insect is from the Island of Bourbon, and for the specimen existing in my own collection I am indebted to Count Mniszech. A remarkable sexual difference occurs both in the formation of the prothorax as well as in the structure of the anterior tibiæ, thus characterized by the author:- 
"Mas: prothorace transversali, tibiis anticis valde arcuatis."

"Femina: prothorace subquadrato, tibiis anticis fere rectis."

\section{Ceratognathus alboguttatus, Bates.}

Ceratognathus sexpustulatus, G. \& H. Cat. Col. iii. 967.

An elaborate description of $C$. alboguttatus is given by Mr. Bates (Ent. Mo. Mag. iv. 54), in which he truly mentions it as one of the smallest species of the Lucanoid Coleoptera, pointing out its affinity to $C$. helotoides, Thomson.

The second name, C. sexpustulatus, has erroneously been recorded by Gemminger and von Harold as being that of a distinct species; the error appears to have arisen from the name sexpustulatus having been originally suggested, and afterwards changed by the author to alboguttatus. The habitat given in the "Catalogus," Moreton Bay, is also incorrect; the species was discovered in the province of Canterbury, New Zealand, by R. W. Fereday, Esq., and at the period of its description was, I believe, unique in Mr. Bates' collection; a second specimen from the same locality has recently been added to my own.

I now proceed to make some observations upon other interesting species, notifying several which are new. For convenience, a list of the novelties is prefixed.

\section{New Genera.}

Psendolucanus, Metadorcus, Pseudodorcus, Lissapterus.

New Species.

1. Chiasognathus impubis, Parry.

2. Metopodontus (?) torresensis,

Deyr.

3. " (?) Swanzianus, Parry.

4. Prosopocoilus mysticus, Parry.

5. Eurytrachelus Candezii, Parry.

6. Sclerostomus tristis, Deyr.

7. marginipennis, Deyr.

8. elongatus, Deyr.

9. Lissotes opacus, Deyr.

10. " Launcestoni,

11.,$\quad$ latidens, Westw.

12. " forcipula,Westw.

13. " furcicornis, $\int \frac{\text { कै }}{8}$

14. $\quad$ Howitt.

15. Cardanus cribratus, Parry.

16. Ceratognathus abdominalis, 


\section{Remarks will also be found on the following :}

1. Chiasognathus Mniszechii, Thoms.

2. Sphenognathus albofuscus,

3. Rhyssonotus foveolatus, Blan.

\section{Thunb.}

4. Lamprima sumptuosa, Hope.

5. Colophon Westwoodii, Gray.

6. Pseudolucanus Mazama, Lec.

7. Dorcus brevis, Say.

8. Odontolabis Burmeisteri, Hope.

9. Odontolabis Castelnaudi, Parry.

10. Gen. Chalcodes, Westwood.

11. Heterochthes brachypterus, Westw.

12. Cladognathus politus, Parry.

13. Metopodontus cinnamomeus,

14. impressus, Guér.

15. Waterh. Maclellandi, Hope.

16. Prosopocoilus Wallacei, Parry. 17. $\quad$ perplexus, Parry. 18.,$\quad$ Archeri, Waterh. 19. " " bulbosus, Hope. 20. " 21. " $"$ antilopus, Swed.
22. Homoderus Mellyi, Parry.

23. Cyclommatus faunicolor, Hope.

24. Prismognathus subœeneus, Motsch.

35. Metadorcus rotundatus, Parry.

26. Leptinopterus Fryi, Parry.

27. Eurytrachelus Bubalus, Perty.

28. " ceramensis, Thoms.

29. " " ternatensis, Thoms. 30. $\quad$ opacus, Waterh. 31. ", fulvonotatus, Parry.

32.,$\quad$ elegans, Parry.

33. Dorcus derelictus, Parry.

34. Agus kandiensis, Parry.

35. Gnaphaloryx dilaticollis, Parry.

36. Pseudodorcus carbonarius, Westw.

37. Sclerostomus cruentus, Burm.

38. Ceratognathus Westwoodii,

39. helotoides, Thoms.

40. Sinodendron americanum, Palisot.

\section{Chiasognathus Mniszechii, Thomson.}

Although this insect was recorded in my former Catalogue (but with some hesitation, see p. 6) as being distinct, I have now little doubt as to the propriety of uniting it with $C$. Jousselinii, Reiche (which name has priority). In this opinion I am confirmed both by Mons. Reiche and Count Mniszech. C. Jousselinii must still be considered a very rare species in our collections; the female is, I believe, unique in the collection of Count Mniszech, and, like the $\delta$ in its normal condition, is densely covered with a silky pubescence.

Chiasognathus impubis, sp. nov. (Pl. I. fig. 5).

๙. Viridi-æneus, purpureo-micans nitidus, lævissimus; mandibulis, gracilibus inclinatis, capite thoraceque parum longioribus apicibus curvatis, irregulariter fere ad medium denticulatis, basi supra spina minuta instructa; capite quadrato, antice læviter emarginato et bitubercu- 
lato, angulis ante oculos acutis; prothorace lateribus antice obliquis, rectis, angulis posticis valde emarginatis, prope angulos profunde foveato, in medio antice canaliculato et irregulariter impresso, sub lente crebre et minutissime punctulato; elytris lævissimis, brunneoæneo-tinctis, confertissime et tenuissime granulatis, pone humeros impressis, linea suturali vix distincta; scutello transverso, rotundato, viridi-metallico, dense punctato; corpore subtus viridi-metallico, valde et dense griseopiloso ; pedibus brunneis, femoribus purpureo-viridibus, tibiis anticis elongatis, curvatis, intus et extus serratodentatis, intermediis et posticis extus minutissime tuberculatis, et prope apicem spina acuta instructis.

Long. corp. (mandib. incl.) unc. 1, lin. 1.

Hab.-Chili. Coll. Brit. Mus., Saunders et Parry.

C. impubis is allied to C. Latreillii, Solier, ㅇ (described also by Mr. Thomson under the name of $C$. Reichii, ô) and of which a figure is given in the present publication (Pl. I. fig. 6) differing, however, in its uniform glabrous appearance, its smooth and shining prothorax, with the mandibles considerably more elongate and deflexed. It is very possible, however, that in a series of specimens of various developments, this insect may ultimately prove to be only the var. max. of $C$. Latreillii. The latter differs in the head being smaller, the mandibles considerably shorter and porrect, the sides of the prothorax more rounded, and slightly subserrate, with the disc exhibiting numerous irregular impressions, the elytra, moreover, being further somewhat rugulose; the anterior legs are also considerably shorter, their tibiæ less curved, and less denticulate internally, and finally, the under surface of the insect is conspicuously less pubescent. These differences may possibly be only abnormal, and produced by the undeveloped condition of the insect; for the present, however, I think it necessary to regard C. impubis as a distinct species. The various specimens hitherto received, were captured at Mendoza, on the eastern side of the Cordillera.

Sphenognathus albofuscus, ㅇ, Blanchard.

The author, in his description of this insect (Voyage de D'Orbigny, p. 193), appears to be in some doubt as

TRANS. ENT. SOC. 1870.-PART I. (MARCH.) 
to its being a well defined species, and alludes to its close affinity with $C$. prionoides $q$, as well as to the singular coloration of the apex, and a portion of the external margin of the elytra, which are of a dusky white, adding that this may be attributable to the bad condition of the specimen. This latter character appears to me, upon a recent examination of the insect in question, to be decidedly abnormal, and its cause doubtful ; upon comparing the insect with a $q$ specimen of $C$. prionoides of an exactly similar development, from my own collection, I can detect no difference, with the exception of a slight variation in the punctuation of the mandibles, and the abnormal colour alluded to; I therefore feel little hesitation in uniting the two insects as one species, the name prionoides having priority.

\section{Rhyssonotus foveolatus, Thunberg. R. nebulosus, Kirby.}

I cannot find any description of $L$. foveolatus in the Mém. Ac. Petr. i. 1806, p. 199, as quoted by Gemminger and von Harold, but I have met with it in the Mém. Soc. Imp. de Moscou, i. 166, accompanied by descriptions of other well-known species by the same author. Thunberg's description of $L$. foveolatus is as follows:"Corpus totum ferrugineum, seu brunneum. Thorax angulatus, convexus, medio stria et foveola obsoleta subpunctatus impressus, lateribus utrinque in disco foveis quatuor impressis. Elytra convexa, lævissima. Femora inermia, tibiis spinosis."

From the above brief description, and the fact that neither the habitat nor a figure of the species is given, I do not think the authors of the "Catalogus" are warranted in suppressing Kirby's name for Thunberg's; and until stronger evidence is afforded of the identity of the two insects, I think it right to maintain Kirby's wellknown designation of $R$. nebulosus, with foveolatus as a doubtful synonym; in this view I am supported by Dr. Burmeister (Handb. v. 336).

Lamprima sumptuosa, Hope.

The great variation in colour exhibited by all the species of this genus, was a difficulty with which describers of species had to contend in former years, from the 
lack of sufficient material to guide them, and we cannot be surprised that errors in the definition of species have so frequently occurred; upwards of twenty different forms have been characterized as pertaining to this genus by various authors, five of which can, I think, alone be retained. L. sumptuosa, belonging to the second section of the genus, was alluded to in my former Catalogue as being a distinct species; the brilliant coppery coloration of the insect, differing so essentially from that of the specimens of $L$. Micardi with which I was then acquainted, caused me, after examining the type specimen in the Hopeian collection, to consider it as distinct; since then, numerous examples of $L$. Micardi have fallen under my notice, exhibiting the diversity of development and colour to which I have above alluded. On comparing recently, at Oxford, a specimen of $L$. Micardi with the type of $L$. sumptuosa, Professor Westwood and myself coincided in opinion as to the propriety of uniting the two. The name Micardi has priority. In reducing the number of species composing the genus Lamprima to five, I am supported by Count Mniszech, in whose rich collection the finest series of specimens, illustrating the different varieties of each species, may be seen.

\section{Colophon Westwoodii, Gray.}

The Berlin Museum possesses both the $\delta$ and $q$ of this very scarce insect, six specimens of which have now fallen under my notice; these are distributed as follows:-in the British Museum (the type specimen), the Hopeian collection at Oxford, the Museum at Halle, my own collection, and the two specimens at Berlin alluded to above. The second species of this genus, described by Professor Westwood, under the name Colophon Thunbergii, remains unique in the Oxford Museum; it is stated to have been received from Caffraria.

\section{Fam. Lucanide.}

The family Lucanidce as constituted in the present Catalogue, and restricted to the genera Mesotopus, Lucanus, Pseudolucanus, Rhatus, and Hexarthrius, I characterize as follows :- 
Eyes (with the exception of the genus Mesotopus) not divided by a canthus.

Clava of antennæ variable $(4,5$, or 6 -jointed), the character of the leaflets variable, but strongly produced in Lucanus and the allied genera, moderately so in Hexarthrius.

Clypeus prominent, and diversiform.

Anterior tibice straight, the four posterior tibiæ of the females invariably armed, and in Mesotopus, Lucanus, and Pseudolucanus, the tibiæ are in both sexes externally pluri-dentate, in Rhoetus and Hexarthrius the intermediate tibiæ of the males are always unidentate, but in the posterior this character is most inconstant, never exhibiting more than a very minute tubercle, which is often found to be both visible and invisible, in the same species.

In their normal condition (var. max.) they attain a considerable size, and with the exception of two species (Hexarthrius Parryi and H. Deyrollii) are unicolorous.

\section{Pseudolucanus Mazama. (Pl. I. fig. 1.)}

Dorcus Mazama, Leconte, Proc. Acad. Nat. Sci. Phil. 1861, p. 345 ; Parry, Tr. Ent. Soc. 3rd ser. ii. 51.

The distinguished American Entomologist Dr. Leconte, on his recent visit to London, very kindly placed in my hands for examination, two very interesting insects indigenous to North America, described under the names of D. Mazama, Leconte, and D. brevis, Say, the former from Northern Mexico, and the latter from New Jersey. Both species were in my former Catalogue included in the genus Dorcus, but the first of the two proves undoubtedly upon examination to be a Lucanus, as hitherto accepted. The form of the prothorax, and the character of the mandibles, which are short, strongly curved, and unidentate, resemble the rare European species L. Barbarossa, Fab. ; in the latter respect it equally assimilates to Lucanus atratus, Hope, from Nepaul, and L. capreolus, Linn., from North America.

The late Mr. Hope has, in his Catalogue, imposed on the two species capreolus and atratus, the generic name Pseudolucanus, and would, without doubt, have included L. Barbarossa, Fab., had he been acquainted with it (the insect mentioned in his Catalogue as belonging to his collection not being the true Fabrician species), and he thus characterizes Pseudolucanus, "Caput 
maris supra haud angulatum," in contradistinction to Lucanus, which he restricts to those species in which "Caput maris supra angulato-elevatum." While accepting the genus Pseudolucanus proposed by Mr. Hope for atratus and capreolus, in which I include the insect under consideration, as well as Barbarossa, I attribute but slight importance to the character given by Mr. Hope (since in the var. minor of the males of many species of Lucanus, it is altogether absent); but characters may be mentioned, which so far as my experience extends, are subject to little or no variation, viz., the size and form of the mandibles. With regard to size, I find on a careful examination of numerous specimens of the several species indicated, that the mandibles seldom exceed the length of the head; and with regard to form, that they are always strongly curved, and never present on their inner edge more than one tooth. I am therefore strongly inclined to believe that these characters will prove to be constant, and that they represent the normal condition of these organs, whereas, in those specimens representing the var. minor of their respective species, their mandibles are porrect, and their internal armature invariably multidentate. The number of the joints in the clava of the antennæ varies in Pseudolucanus as it does in Lucanus, $P$. Barbarossa exhibiting six, while each of the other three species, P.atratus, P. capreolus, and P. Mazama exhibits only four.

P. Mazama differs from the allied species of the genus in its broad and exceedingly short clypeus, which is slightly concave, in the angles of the head behind the eyes being more prominent, in the anterior angles of the prothorax being very much produced, and finally in its punctuation, which is uniform on the entire surface, and although diffuse, is strong and very apparent; the colour of the insect is dull rufous; it is, I believe, unique in Dr. Leconte's collection. The $q$ is still unknown.

\section{Dorcus brevis, Say.}

With respect to the insect noted as Doreus brevis of Say, I have, after most careful examination and comparison with numerous specimens of Dorcus parallelus, Say, a not uncommon North American species, arrived at the conclusion, that the specimen in question must be considered as only an old worn state of $D$. parallelus in which 
the striæ of the elytra have become obsolete, the apex of the mandibles blunt, and the teeth of the tibiæ considerably worn down, thus modifying its usual appearance; and Say's description appears to me to afford nothing opposed to this view.

\section{Fam. Odontolabide.}

The genera Odontolabis, Chalcodes, Heterochthes and Neolucanus, hitherto located in the Lucanidae, present the following characters in common which distinguish them generally from the Lucanidae and Cladognathidae, and are sufficient, in my opinion, to entitle them to rank as a distinct family.

Clava of antennce tri-articulate, the leaflets being but moderately produced.

Clypeus remarkably small, considering the size of the insect.

Eyes divided in both sexes by a canthus.

Tibice: anterior tibiæ in the males often considerably curved, their external armature very variable. Four posterior tibiæ in both sexes invariably unarmed.

The majority of the species are of large size, and chiefly bicolorous.

\section{Odontolabis Burmeisteri, Hope.}

At the time of preparing my former Catalogue a single specimen only ( $f$ var. max.), in the Hopeian collection at Oxford, was known, and I ventured the suggestion that the insect might possibly prove to be only an extreme variety of $O$. Cuvera, Hope. Count Mniszech has recently received from the Mysore, a specimen of the var. minor, and assures me that $O$. Burmeisteri should be accepted as a distinct species.

\section{Odontolabis Castelnaudi, Parry. (Pl. III. figs. 4, 5, 6.)}

When notifying this very rare species from Sumatra, two specimens only were known to me, one in my own collection (var. med.) and the other (var. minor) in that of M. Laporte de Castelnau. Recently Count Mniszech has obtained a specimen of the var. max. from the same locality. Figures are now given showing the 
varied development of the mandibles to which these gigantic insects are subject. The form and character of these organs of the var. max. in their normal condition, as shown in the figure, lead me now to place this species in the section of Odontolabis to which O. Stevensii belongs. The female is as yet unknown.

\section{Genus Chalcodes.}

Calcodes, Westw. Ann. Sci. Nat. ser. 2, i. 118 (1834); and in Hope, Cat. Luc.

In my former Catalogue I included this genus in Odontolabis as a section comprising four species, ceratus, cingalensis, nigrita, and intermedius. As it now appears desirable to reinstate the genus Chalcodes, it is necessary to modify and amplify the short characters assigned to it (corpus metallicum, tibiæ et tarsi subtus setosi) by Professor Westwood, in Mr. Hope's Catalogue:-

Corpus metallicum, vel nigrum, nitidum ; caput antice angustatum, pone oculos modice inflatum, inarmatum; tibiæ anticæ ut in Odontolabe sæpe curvatæ, hæ intus et tarsi subtus setosi.

\section{Heterochthes brachypterus, Westwood.}

This rare species, discovered by the late Mons. Mouhot, in Siam, has recently again been received by Dr. Kaup, of Darmstadt, and distributed in various collections; the specimens in question are stated to have been received from the Island of Nias, on the Coast of Sumatra, but the habitat thus assigned is, I believe, erroneous.

\section{Fam. Cladognathide.}

Admitting the difficulty I experienced in proposing a more satisfactory arrangement of the insects pertaining to the genus Cladognathus of my former Catalogue (see p. 21), I was then compelled to content myself with a mere sectional arrangement. Since that period much valuable information has become available, which induces me on the present occasion, to propose a fresh grouping: of the numerous species contained in it, and the allied genera, Homoderus, Cyclommatus, Prismognathus, Can- 
tharolethrus, Leptinopterus, and Macrocrates; these, altogether, amount to about a quarter of the entire Lucanoid Coleoptera, and I propose to raise them into a distinct family Cladognathidee, differing as they do in so many respects from the Lucanidae and Odontolabidae.

The family may be characterized as follows :-

Clava of antennæ tri-articulate, leaflets moderately produced.

Clypeus small, indistinct.

Eyes never entirely divided by a canthus.*

Anterior tivice in the males straight; armature of the four posterior tibiæ variable in the males, unidentate in the females (with the exception of two species, Prosopocoilus cavifrons and $P$. approximatus).

The species in comparison with the Lucanidae and Odontolabidae are of moderate size, and variable in colour.

The numerous species contained in the old genus Cladognathus, I now propose to group in the following genera:-

1. Cladognathus, Burm.; now limited to three species only.

2. Psalidoremus, Mots. (substituted by the author for Psalidognathus, see Etudes Entom. 1862); only two species from Japan are at present known, assimilating in general form to many of the species of Metopodontus, differing, however, in their mandibles being considerably more deflexed, in the total absence of tubercles on the head, with a flat process (lamina) between the mandibles, and immediately above the clypeus, and finally in their colour, which is of a rich dark chesnut.

3. Metopodontus, Hope ; insects exhibiting great diversity of form and sculpture in the various stages of development; the upper surface of the head in the var. max. is invariably tuberculate, but in the var. minor this latter character is most inconstant; the species composing this genus are unicolorous and bicolorous.

4. Prosopocoilus, Hope; by far the greater number of the species composing the family are contained in this genus, and will, I have no doubt, hereafter be subjected to further subdivision; for the present, I must con-

* An exception occurs in two species, Prosopocoilus Archeri and Prosopocoilus forceps. 
tent myself with a sectional arrangement, which, however, is not quite satisfactory as regards certain of the species; few of them attain any very considerable size, they exhibit great similarity in general form, differ considerably in the armature of the tibiæ as well as in the dentition of their mandibles, and, with the exception of a somewhat anomalous species from Borneo (P.passaloides) in which the elytra in both sexes are punctatestriate, their surface is generally glabrous and shining, and their coloration variable.

The Cladognathidae appear to assimilate more closely to the Dorcida, more especially to the genera Eurytrachelus and Dorcus; besides the differences already pointed out by Dr. Burmeister and Professor Lacordaire, I may mention that the females of the Cladognathidce are invariably destitute of the tubercles on the head, a character so constantly exhibited in the females of Eurytrachelus and Dorcus.

\section{Cladognathus politus, Parry.}

Among the species presenting difficulty as to their proper location is C.politus, of which I received a single specimen (probably only the var. minor, the mandibles being scarcely longer than the head) from Mr. Bowring's collection. Although the habitat India was assigned to it in my former Catalogue, I have now some reason to suppose that either China or the Indian Archipelago may ultimately prove to be correct. Unfortunately the abnormal condition of the mandibles, as shown by their size in comparison with the total length of the insect, as well as our ignorance of the female, renders its true position very problematical. Taking into consideration, however, the deeply emarginate front of the head, of which the anterior angles are bisinuate, the armature of the posterior angles of the prothorax, and the smooth and polished appearance of the insect, and its strongly armed tibiæ, I have deemed it advisable to locate it temporarily in the genus Cladognathus as at present restricted.

Metopodontus cinnamomeus, Guérin.

A form somewhat aberrant from the Javanese specimens of this insect, and representing the var. max., is contained 
in the National collection, received from Hong Kong; it differs from the ordinary larger males in having the mandibles somewhat flexuous, being bent inwards near the base, and with the tooth which is usually found there placed midway between the basal bend and the apex, the three apical teeth retain their usual position. The head is very broad, the cavity between the mandibles and that behind the tubercles on the disc are deeper. The thorax has the central portion unusually shining. The elytra are proportionally broader at the base, the suture being black. The coloration of the insect is that of cinnamomeus, mandibles reddish-brown, head and thorax chesnut-brown, elytra fusco-testaceous, with the lower portions of the femora and the base and apex of the tibiæ and tarsi black.

I may mention that I have recently seen specimens in the collection of the Jardin des Plantes, sent from Pekin by the Missionary Père David, closely approximating to $M$. cinnamomeus, but still more so to M. castaneus, Hope, from Northern India, and considered as distinct both by Count Mniszech and Mons. Blanchard. I was informed that the latter gentleman has undertaken to describe this insect, as also a new species of Dorcus (? Gnaphaloryx) from the same locality, allied to Dorcus velutinus, Thomson. Anxious to include them in my synopsis, I wrote some time back to Mons. Blanchard requesting that he would kindly furnish me with the names under which he intended to describe them, but up to the present period I have received no answer to my communication.

\section{Metopodontus impressus. (Pl. III. fig. 1.)}

Cladognathus impressus, Waterh. Tr. Ent. Soc. 1869, p. 17.

Since the publication of Mr. C. Waterhouse's description of this species, of which single specimens only then existed in my own cabinet and in the National Collection, two other specimens have fallen under my notice, communicated through the kindness of Mr. E. Brown, which enable me to locate this species with greater certainty in the genus Metopodontus. Notwithstanding that these specimens do not represent a maximum development of the insect, still the existence of tubercles (from which the genus is characterized) on the anterior margin of the 
head is fully apparent; in the var. minor of the species this character is often wanting. M. impressus assimilates in general form to the allied species $M$. castaneus and $M$. foveatus, its coloration, however, is not uniform, a somewhat indistinct black plaga existing on the centre of the prothorax and elytra. The fossa noticed on the head between the eyes in the var. minor, does not appear to exist in the specimen in question.

\section{Metopodontus Maclellandi.}

Lucanus McLellandi, ठ, Hope (var. minor) Tr. Ent. Soc. iv. 74 .

Cladognathus quadrinodosus, ô, Parry (var. max.) Tr. Ent. Soc. ser. 3, ii. 22, pl. viii. fig. 4.

We have here another instance of the difficulty in appreciating species unless the author has before his eyes a series of specimens exhibiting the various gradations of growth in the mandibles. I have already stated that the entire sculpture of a species alters with the condition of these organs; not so, however, its size; the outward form of species both with developed and non-developed mandibles being generally found identical, although the sculpture may vary considerably. The present insect affords an excellent illustration of these facts, elucidated from a series of specimens now in my possession, in which the mandibles exhibit four different gradations of development, and had I possessed these specimens when describing $C$.quadrinodosus, the error alluded to could not have occurred. The very peculiar character of $C$. quadrinodosus, which is not to be met with in any other insect belonging to the Lucanoid Coleoptera, viz., the being furnished on its vertex with four distinct tubercles, led me naturally to consider it as a distinct species, differing as it does so greatly in this, as in several other respects, from $C$. Maclellandi, the latter being totally devoid even of the faintest trace of tubercles. C. Maclellandi may be considered as the lowest development of the species, and be represented as No. 4. In No. 3, the next stage in growth of the mandibles, a trace of the tubercles already exists, which in No. 2 becomes stronger, and in No. 1, represented by $C$. quadrinodosus, they are exceedingly prominent, and, as I believe, the insect then attains the maximum of growth.

The female of $C$. Maclellandi has not yet fallen under my notice. 
Metopodontus (?) torresensis, n. sp. (Pl. I. fig. 3 \& , 4 o o.) Cladognathus torresensis (H. Deyr. M. S.). *

"In form resembling $C$. bison, but only half its size, and of a different colour. Somewhat shining, of a deep brown, with a narrow, ill-defined, slightly paler stripe along the sides of the elytra, more apparent towards the shoulders, often obliterated posteriorly; a spot of the same colour towards the middle of the sides of the prothorax. Mandibles slightly arcuate, each armed internally at the base with a large depressed tubercle as in C. bison.

Head strongly excavated in front, the excavation limited by a horizontal ridge, which surmounts it and is slightly semicircularly emarginate, and formed by the anterior margin of the forehead.

Prothorax a trifle wider in front than behind, its anterior margin strongly bisinuate; anterior angles prominent, the posterior obliquely truncate, the truncature dentiform at its anterior angle; sides broadly rounded in front, sinuously contracted behind.

Elytra parallel, conjointly rounded behind, humeral angles dentiform.

Punctuation of the male somewhat dense, and rather obsolete on the disc of the elytra; that of the head and prothorax somewhat sparse, conspicuous on the sides only, on the disc merging into a very fine granulation which imparts to the head, and a trifle less to the prothorax, a duller aspect than that of the rest of the body.

Beneath blackish, very shining.

q. As in the other species of the genus, more shining, and more strongly punctate than the male; easily recognized by its wide prothorax, parallel at the sides, and with its anterior angles broadly rounded.

Hab.-Torres Straits. $\delta$, ㅇ․ Coll. Mniszech.

Obs. The only female at present received is of a lighter colour than the male, but I consider this to be an individual peculiarity, and not a general character."

(H. Deyrolle.)

* For the description of this new and interesting species, and likewise for others hereafter given, I am indebted to Monsieur Henri Deyrolle, the well-known French Entomologist, and able Curator of Count de Mniszech's rich collection of Coleoptera, wherein are preserved the types of the several species described. It is probable that this insect represents the var. minor, and that in the var. max. the head will prove to be bituberculate, as in Metopodontus bison. I have, therefore, located it in the genus Metopodontus; its true habitat, Count Mniszech informs me, is the extreme northern part of Australia. 
Metopodontus (?) Swanzianus, n. sp. (Pl. II. fig. 2.)

Parum nitidus, castaneus; thorace ferrugineo-brunneo, disco punctoque in medio prope latera nigris; elytris ferrugineo-brunneis, sutura marginibusque anguste nigricantibus ; mandibulis capite brevioribus, intus irregulariter quinque-dentatis; clypeo parvo, binodoso ; capite antice angustato, pone oculos inflato, crebre punctulato ; prothorace transverso, lateribus rotundatis, confertissime punctulato, punctis majoribus sparsis; elytris paulo convexis, punctatis; corpore infra castaneo, metathorace plagis duabus flavis ornato; pedibus nigro-castaneis, tibiis inermibus.

Long. corp. (mandib. incl.) lin. 9.

Hab.-Afric. oce. Coll. Parry.

This elegant little species has on a cursory inspection a very strong resemblance to Metopodontus Savagii (var. minor, Pl. II. fig. 4); its armed mandibles, the form of its head and clypeus, and the colour of its legs, afford, however, ample distinguishing characters. Acquainted with the $\delta$ var. minor only, I refer it provisionally to the genus Metopodontus, the minor development in several of the species of this genus being destitute of the tubercles in front of the head so conspicuous in the var. max. as already stated. I have great pleasure in naming this insect after my friend Mr. Swanzy, from whose interesting collection of West African Lucanoidea I have obtained much valuable information, and to whom I am indebted for the addition of this unique insect to my collection.

\section{Prosopocoilus Wallacii, Parry.}

I am indebted to M. Van Vollenhoven for the addition of this rare species to my collection. An unique specimen of the $\delta$ captured by $\mathrm{Mr}$. Wallace, was described in my former publication. The following brief diagnosis may be sufficient to characterize the female.

q. Niger, supra nitidissimus, subparallelus; elytris dorso fusco-castaneis, linea angusta fulva ab humero fere ad apicem ducta notatis, marginibus nigris.

Long. corp. unc. 1, lin. 2.

Hab.-Halmaheira (Gilolo).

Slightly convex, above very shining. Head subquadrate, in front and at the sides with large shallow and often confluent punctures, behind smooth, rounded in front of the eyes; mandibles short, strongly punctate, slightly grooved on the upper surface, and armed with a short 
obtuse tooth, situate internally near the apex; prothorax with the anterior and posterior angles rounded, very minutely and sparsely punctate on the disc, but coarsely so at the anterior angles; scutellum obsoletely punctate; elytra smooth on the disc, the lateral margins thickly punctate; the four posterior tibiæ armed with a strong spine.

\section{Prosopocoilus perplexus, Parry. P. natalensis, Parry (Pl. II. figs. 6, 9). P. approximatus, Parry (Pl. III. figs. 2, 7).}

The specimen from which the description at p. 26 of my former Catalogue was derived belonged to Mr. Bowring's collection and was noted with the habitat "Ind. or.;" the name perplexus was assigned to it, to denote some hesitation in my mind as to its affinity with other allied Indian species of the genus, with none of which it appeared exactly to coincide. Since then, I have in the British Museum met with another male specimen (also a var. minor) as well as two females; of the latter, one specimen was presented by Captain Boys from Northern India, and the other two were obtained from the collection of the East India Company. The habitat of India is, therefore, I think, perfectly correct.

Recently on a visit to Paris, both Count Mniszech and Mons. H. Deyrolle having expressed a strong opinion as to $P$. perplexus being only a variety of $P$. natalensis (to which it certainly bears a very great similarity), I have, conjointly with Mr. C. Waterhouse, carefully compared the various specimens of $P$. perplexus with those of $C$. natalensis, and find that $P$. perplexus is of a somewhat lighter colour, has comparatively narrower and less quadrate elytra, its clypeus is simple, its head closely granulate, and with a few large punctures at the sides behind the eyes, its thorax thickly granulate all over, and presenting no trace whatever of punctures, and the punctuation of the elytra is much finer and sparser.

Figures are now given also of the var. max. and var. med. of $P$. approximatus.

\section{Prosopocoilus mysticus, n. sp.}

§. Castaneo-piceus, nitidus, depressus, supra et subtus confertissime granulosus; mandibulis capitis longi- 
tudine, apicibus curvatis, acutis, intus irregulariter denticulatis, basi emarginatis; capite subquadrato, fronte antice depressa, emarginata, lateribus fortiter et grosse punctatis, angulis ante oculos obtusis, pone oculos leviter inflatis; clypeo parvo, binodoso ; thorace transverso, angulis posticis obliquis, margine antico fulvo-ciliato; elytris crebre punctatis, ad suturam sublævibus; scutello triangulari, sparsim punctulato; pedibus rufo-piceis, tibiis extus inermibus, intus ciliatis, tarsis subtus fulvohirtis.

Long. corp. lin. 10 ; mandib. lin. $2 \frac{1}{2}$.

Hab.-Malacca. Mus. Parry et Mniszech.

This new species is closely allied to P. cilipes, Thomson, from Assam; but is at once distinguished by the structure of its mandibles, the smooth lateral margins of its prothorax, its unarmed tibiæ, and the normal length of its tarsi; whereas, in $P$. cilipes, the mandibles are provided internally, at their base, with a large bifid tooth (whereof no trace exists in P. mysticus), the lateral margins of the prothorax are strongly crenulate, the four posterior tibiæ are armed with a single spine, and the tarsi attain extraordinary proportions, being about onethird longer than their respective tibiæ.

\section{Prosopocoilus Archeri.}

Aulacostethus Archeri, C. Waterh. Tr. Ent. Soc. 1869, p. 14, pl. iii. fig. 1 .

I am somewhat perplexed in locating the insect for which Mr. C. Waterhouse has proposed a new genus, and of which the characters given are as follows :-

" 1st. The form of the mentum varying from all other species belonging to the Lucanidae.

" 2 ndly. The eyes being entirely divided by a canthus.

"3rdly. The prosternum being narrow and longitudinally canaliculate.

" 4 thly. The four posterior tibiæ being most conspicuously enlarged at their extreme apex, with the tarsi remarkably short."

The author's first idea of referring this insect to the Cladognathida appears to me to be correct, exhibiting as 
it does, in general form and character, a very marked resemblance to several species now included in the genus Prosopocoilus, and more especially to P. Spencii, Hope, of which a figure is now given (Pl. II. fig. 1). Whether the characters adduced by $\mathrm{Mr}$. Waterhouse are sufficient to warrant the creation of a new genus, may, perhaps, admit of some doubt, as in reference to three of the characters, viz., the form of the mentum, the canaliculate prosternum, and the eyes divided by a canthus, these are also present in Prosocopoilus forceps from Sumatra, which species, on account of the peculiar character of the armature of the mandibles, has been located in the same section as $P$. Spencii, $P$. bulbosus, and others, and might, possibly, with equal propriety be raised to generic rank, looking at the very great difference this insect exhibits from any other of the species of the family, in the singular formation of the mandibles, so conspicuously forcipiform, in the eyes being divided by a canthus, and finally, in the peculiarly sinuate sides of the prothorax. In reference to the apical dilatation of the four posterior tibiæ, as remarked in $P$. Archeri, this character (although somewhat modified) is very conspicuous in Psalidoremus Motschulskii, and still more so in two species belonging to the Dorcida, viz., Pseudodorcus carbonarius, West., and Sclerostomus Bacchus, Hope. The extreme brevity of the tarsi is certainly most peculiar in this species, and not to be met with in any other belonging to this family, but is, I think, scarcely of generic value. Taking, therefore, into consideration these facts, I deem it preferable, for the present, to place this species in the genus Prosopocoilus. The female is at present unknown.

\section{Prosopocoilus Spencii. \\ Prosopocoilus bulbosus.}

Lucanus bulbosus, Hope, Cat. Luc. p. 20 (clypeo bituberculato); nec L. bulbosus, Hope, Tr. Linn. Soc. xviii. 589 , pl. xl. fig. 2 (clypeo unituberculato).

Having recently remarked the discrepancy in the form of the clypeus described by $\mathrm{Mr}$. Hope in his Catalogue of Lucanidae, and the figure given of $L$. bulbosus in the Trans. Linn. Soc., that organ being described in the former as bituberculate, whereas in the latter it is indubitably unituberculate, it becomes apparent that two 
distinct species were confounded by $\mathrm{Mr}$. Hope under the name of $L$. bulbosus. As regards Mr. Thomson's Prosopocoilus crenicollis, there exists no doubt in my mind, that, misled by the description given by $\mathrm{Mr}$. Hope in his Catalogue, and without consulting the figure anteriorly published in the Linnean Transactions, and cited by Mr. Hope, he erroneously considered the insect before him as a nondescript, whereas it now proves to be identical with $L$. bulbosus, Hope, of the Trans. Lin. Soc., and of which I consider $L$. Spencii to be the var. max.; the descriptions of the several insects alluded to amply confirm the opinion I have expressed.

The synonymy will therefore stand thus:-

\section{Prosopocoitus Spencii. (Pl. II. fig. 1.)}

Lucanus Spencii, ơ (var. max.) Hope, Tr. Linn. Soc. xviii. 589.

Macrognathus Spencii, Hope, Cat. Luc. p. 6 and p. 19. Cladognathus Spencii, Parry, Cat. p. 37.

Lucanus bulbosus, ठ์ (var. min.) Hope, Tr. Linn. Soc. xviii. 589, pl, xl. fig. 2 (clypeo unituberculato).

Dorcus punctiger, 우, Hope, Tr. Linn. Soc. xviii. 592. Prosopocoilus crenicollis, $\delta$ \& , Thomson, Cat. Luc. p. 418.

Mr. Thomson suggests the possibility of the two insects representing only a difference in race, or hereditary or local varieties of the same species, but I think that the diversity exhibited in the clypeus, as well as in the different armature of the mandibles, and the more attenuate form of the elytra so conspicuous in $C$. bulbosus, fully warrant the conclusion, that $C$. bulbosus, Hope, Cat., and C. Spencii, Hope, Tr. Linn. Soc. are distinct species.

\section{Prosopocoilus antilopus, Swed.}

Cladognathus quadridens, Hope.

Both the figure and description of the mandibles " exsertæ, capite vix longiores," show that the insect described by Swederus (Act. Holm.1787, p. 186, pl. viii. fig. 3) is the var. minor of the species ; it is stated to have formed part of the then celebrated Drury collection, dispersed, I believe, afterwards by public auction. Allusion was made in

TRANS. ENT. SOC. 1870.--PART I. (MARCH.) 
my former Catalogue (p. 35) as to the probable identity of antilopus and the quadridens of Hope (Cat. Luc. p. 4), and this view has been confirmed, from having had the opportunity of examining a larger number of specimens of the insect in all its developments. In the present Catalogue, I unite them as one species.

\section{Homoderus Mellyi.}

ơ (var. min.) Parry, Tr. Ent. Soc. ser. 3, ii. 38.

o (var. max.) H. Deyrolle, Ann. Soc. Ent. Fr. 1864, p. 316, pl. iv. fig. 2.

Gen. Homoderus. Clypeus with its anterior angles produced into a more or less acute slightly recurved tooth, broadly emarginate in front; antennæ elongate; mandibles falcate, toothed internally; head (in var. max.) strongly raised in front.

The characters of the genus Homoderus originally given were taken from a specimen then unique in my collection, which now proves to be the var. minor. Since that period many specimens have been received, among them a gigantic insect representing the var. max.; it is in Count Mniszech's collection, was captured by Dr. Moufflet on the Gaboon, West Africa, and a short notice of it accompanied by a figure has been given by M. H. Deyrolle. The remarkable head of the var. max. necessitates some modification of the characters at first attributed to this interesting genus, which approximates to Cyclommatus in the structure of the head, as well as in the elongate antennæ, a ready transition being afforded through $\mathrm{Cy}$ clommatus Kaupii from Celebes, a new species recently described by M. H. Deyrolle, from Count Mniszech's collection.

\section{Cyclommatus faunicolor, Hope. \\ C. Maitlandi, Parry.}

The specimen in the Museum at Amsterdam (since presented to that of Leyden) which was described and figured in my former Catalogue under the name of $C$. Maitlandi must now, upon the authority of M. Snellen van Vollenhoven and Count Mniszech, be considered as representing only the var. $\max$. of $C$. faunicolor, Hope: 
allusion was there made to the affinity of the two insects, and the rich dark purple colour of the elytra of C. Maitlandi was adduced as the distinguishing character between it and the other allied species; this character has, however, now proved to be abnormal, Count Mniszech having: lately received specimens of the same development which have the elytra covered with the silken pubescence of the var. minor (C.faunicolor, Hope). The name Maitlandi is therefore to be sunk as a synonym.

Prismognathus subceneus, के, Motsch. in Schrenck. Reis. Col. 138, pl. ix. fig. 12 (1860).

Metopodontus dauricus, \&, Motsch. lib. cit. p. 137, pl.ix. fig. 11.

Prismognathus dauricus, $\delta$ and $\$$, Motsch. Et. Ent. 1861, p. 10.

Cladognathus dauricus, Parry, Cat. p. 81.

Cyclorasis Jekelii, Parry, Tr. Ent. Soc. ser. 3, ii. 41.

Hab.-Chowsan, Corea, Mantchouria, Pekin.

Prismognathus subceneus and Metopodontus dauricus were originally described as distinct species, and subsequently indicated by the author as identical, and to be united under the name of $P$. dauricus. In 1864, I received from Mr. Bowring the $\delta$ and $q$ of an insect from Chowsan, which I considered new, and described under the name of Cyclorasis Jekelii; having since examined other specimens in Count Mniszech's collection, and also in that of the Jardin des Plantes, received from Pekin and Mantchouria, my attention has been drawn to the descriptions and figures given by Col. Motschulsky, and I have every reason to believe that the two are really identical. One of the chief characters of the genus in which I had placed it, "oculi rotundati, integri" is unnoticed by Motschulsky, who characterizes it as being remarkable for the prismatic colouring of the mandibles, which are also strongly grooved on their upper surface, and furnished with a sub-erect tooth near the apex. Although Mr.Thomson's name of Cyclorasis is undoubtedly more appropriate, it must nevertheless, in right of priority, yield to Prismognathus of Motschulsky; the specific name of subceneus, representing the male, ought however to be retained. 


\section{Metadorcus, n. g.}

Head broad, strongly tuberculate behind the eyes, anteriorly emarginate.

Antenne short.

Clypeus broad, slightly emarginate.

Mandibles slightly longer than the head, robust, arcuate, internally furrowed, with a strong sub-erect tooth near the centre, apex bifurcate.

Prothorax somewhat broader than the head, posterior angles oblique and emarginate, sides slightly sinuate.

Elytra narrower than the thorax, very short and convex.

Tibice, four anterior indistinctly denticulate, posterior unarmed.

\section{Metadorcus rotundatus.}

Leptinopterus rotundatus, Parry, Cat. Luc. p. 43.

This South American species somewhat resembles Macrocrates Bucephalus, Burm., and might be mistaken for the var. minor of that species. The latter differs in the mandibles being considerably longer, equally robust, but straight instead of circumflexed, in the clypeus being: considerably more apparent, broad, and slightly emarginate, with the lateral angles acute; the head also is much broader, with the anterior margin nearly straight, and the antennæ are much more elongate.

The insects composing the genus Leptinopterus, in which genus $M$. rotundatus was formerly located, differ in having the mandibles less robust, more porrect, and but slightly arcuate, the armature more variable, the head unarmed behind the eyes, the elytra considerably more elongate and depressed.

The great difference in the form of the prothorax, and in the character of the mandibles, the very slight armature of the tibiæ, the posterior being totally unarmed, separate it, I think, from those species of the Dorcidae pertaining to the South American genus Sclerostomus, to which it somewhat assimilates, and I place it as the link between Macrocrates and Leptinopterus. Judging from the specimens with which I am aquainted, I am under the impression that they are referable to the var. $\max$. 


\section{Leptinopterus Fryi, Parry.}

A second specimen of this rare insect, hitherto unique in my own collection, exists in the Berlin Museum; it differs as to the size of the mandibles, these being considerably shorter, and consequently denoting a var. minor, The female appears still to remain unknown.

\section{Fam. Dorcider.}

It appears to me advisable, with a view of facilitating the general arrangement of the insects belonging to this family, to separate them into two distinct divisions; and to include in the first division the genera containing species of a large or moderate size, in which, in their normal condition, the mandibles attain a maximum development, and are porrect, and often considerably exceed the length of the head; moreover, the several species exhibit a certain marked uniformity both of form and colour. Their habitat, too, with four exceptions (Dorcus parallelus, D. parallelipipedus, D. Musimon, and D. Peyronis), is confined to the Continent of India, China, and to the Islands of the Indian Archipelago.

In the second division, I locate the genera composed of insects usually presenting a very minor development of mandibles; these are often recurved, seldom exceed the length of the head, and exhibit a greater diversity of form, sculpture, and colour; their habitat, moreover, is exclusively confined to Europe, Africa, the American Continent, and Australia.

\section{Eurytrachelus Bubalus, Perty.}

In my former Catalogue, this was recorded as a distinct species, a suggestion being made that it would, perhaps, ultimately prove to be a var. min. of either $E$. Titan or E. Bucephalus; having since obtained specimens showing the various gradations of form exhibited in E. Bucephalus, one of which, a var. minor, corresponds exactly with Perty's description of Bubalus, I no longer entertain any doubt as to their specific identity. It has I believe, been suggested by some entomologists, that E. Bucephalus (of which an excellent figure is given by Perty) and E. Titan are identical; in this view I cannot participate, seeing the very marked differences exhibited by these insects in the clypeus, and in the form of the 
mandibles. A considerable difference is also to be observed in the females of the two species; the punctuation in E.Bucephalus, $q$, is much stronger, and the elytra are partially covered with a short sub-erect golden pubescence, and are more strongly lineate. The following three species, E. Titan, chiefly from the islands of the Eastern Archipelago, E. Westermani, from India, and E. platymelus from China and Formosa, appear to me to be more closely allied, and might, perhaps, be considered as geographical varieties. I may add, that on my attention being called to the habitats of $E$. Bucephalus given in my former Catalogue, viz., "India, Archip. Ind.," I have examined numerous specimens, contained in various collections, and find that the habitat is exclusively Java. I now give figures of E. Tityus, Hope (Pl. III. figs. 3, 8).

\section{Eurytrachelus ceramensis, Thomson.}

In my former Catalogue I referred this insect to $E$. concolor, Blanchard; Count Mniszech and M. H. Deyrolle have, however, expressed to me their opinion that it is distinct, and as I do not possess authentic specimens of Mr. Thomson's insect, it is, perhaps, advisable to retain it as such until further information is obtained.

\section{Eurytrachelus ternatensis, Thomson. \\ E. Thomsoni, Parry.}

The insect described at page 47 of my previous Catalogue under the name of $E$. Thomsoni, has proved to be identical with Mr. Thomson's species, "Catalogue des Lucanides," p. 423; the name must, therefore, be suppressed in favour of E. ternatensis.

\section{Eurytrachelus Candezii, n. sp. (Pl. I. fig. 2.)}

E. niger, nitidissimus, totus unicolor, politus ; prothorace utrinque impressionibus duabus singulariter auriculiformibus indentato. ( $\delta$ var. min.).

$E$. ternatensi affinis, at nitidior; capite prothorace paulo angustiore, antice depresso, in medio et postice parce, lateribus crebre et fortiter punctato; mandibulis capite paulo brevioribus, punctulatis, prope basin binodosis, interneque excisis; clypeo emarginato, transverso, 
angulis obtusis; prothorace nitido, lateribus antice et postice sinuatis, disco subtilissime punctulato, in medio tenuissime canaliculato, lateribus grosse punctatis; elytris disco sub lente sparsim punctulato, lateribus et ad basin fortiter punctatis; scutello sparsim punctulato; corpore subtus crebre punctulato et tenuissime villoso; pedibus ciliatis, tibiis anticis fortiter et irregulariter serratis, posticis quatuor unispinosis. ( $q$ incogn.).

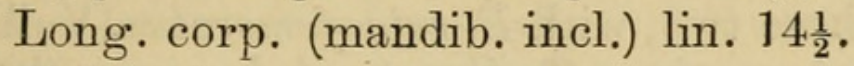

Hab.-Java.

This species was kindly added to my collection by $\mathrm{Dr}$. Candèze, the well-known entomologist of Liège ; a knowledge of the var. max. would be highly interesting, in regard especially to the singular impressions on the prothorax, no other instance of the same kind occurring in any of the allied species of this genus.

\section{Eurytrachelus opacus.}

Macrodorcas opacus, C. Waterh. Ent. Mo. Mag. vi. 208.

A single specimen (var. min.) from Japan, is in the British Museum. It appears to be closely allied to niponensis, Voll., now placed in the genus Eurytrachelus. E. niponensis may, I think, with great probability prove hereafter to be identical with Macrodoreas rectus of Motschulsky, but for the present it is, I think, advisable to retain it in the position it has hitherto occupied; and I am further of opinion that, should niponensis prove to be identical with rectus, upon which the genus Macrodorcas was founded, it is not entitled to generic rank.

Eurytrachelus fulvonotatus.

Cladognathus fulvonotatus, of (var. max.), Parry, Cat. p. 81.

Cladognathus bisignatus, ơ (var. min.) क , Parry, l.c.

Having now examined numerous specimens of $C$. bisignatus, I am fully satisfied that it and fulvonotatus ought to be united, bisignatus of representing the var. minor, in which the fulvous marginal line of the elytra present in $E$. fulvonotatus is reduced to a mere apical dash, and the fulvous spots of the thorax are entirely obliterated. 
My modified views respecting the limits of the genus Cladognathus render it necessary to remove this species, and I now locate it in Eurytrachelus, with certain species to which it assimilates in the form of the mandibles, in the structure of the head and clypeus, and especially in the tuberculate head of the female (this last character never occurring in the females of the genera composing the Cladognathidae). Its nearest ally in form is E. niponensis, Voll., and these two, with E. rubrofemoratus, Voll., from Japan, form a section of Eurytrachelus, possibly representing the genus Macrodorcas of Motschulsky, and I have almost arrived at the conclusion that Macrodorcas rectus is identical with E. niponensis. Mr. C. Waterhouse in his recent description of Macrodorcas opacus (vide ante, p. 91) evidently indicates the same conclusion.

\section{Eurytrachelus elegans.}

Cladognathus elegans, Parry, Cat. p. 27, $\delta$ ( $q$ incogn.).

Unfortunately I am not in a position to state whether the female has or has not the vertex of the head bituberculate, but in other respects it assimilates so closely with the preceding as to lead me to refer it without hesitation to the genus Eurytrachelus, and to remove it from Cladognathus where I formerly located it, but from which it differs widely in the structure of the head, clypeus, and mandibles. This insect formed part of Mr. Bowring's collection, and although the habitat of India was assigned to it, I think it not unlikely that either China, Siam, or one of the Islands in the Eastern Archipelago may eventually prove to be more correct. With respect to colour, however, this species and the foregoing form an exception, all the other members of this division of the family being of a dusky brown or black hue.

\section{Dorcus (?) derelictus, Parry. (Pl. II. fig. 3.)}

Since the publication of my description of this singular insect, of which the sex appeared to me doubtful, I have been enabled by dissection to ascertain beyond doubt that it is a female. The strongly bituberculate head induced me formerly (with some hesitation) to place it with the Dorcida, but I am now inclined, on account of its uniform glossy and comparatively impunctate surface, 
coupled with the form and slender character of its legs, and its unarmed posterior tibiæ, to consider that this species is perhaps more closely allied to the Cladognathidoe, or to the Odontolabidae, the latter having the posterior tibiæ in both sexes unarmed. The singular anomaly of having the posterior tibiæ unarmed in this sex of the Cladognathidae, has fallen under my notice only in two species, Prosopocoilus cavifrons and $P$. approximatus; nevertheless as a knowledge of the male sex can alone declare its true position, I prefer for the present to locate it temporarily in the fourth section of the genus Dorcus, together with two other insects, the males of which are at present unknown.

\section{Agus kandiensis, Hope. (Pl. II. figs. 5, 8.)}

Under some reservation, two insects from Borneo and the Philippines were united (Cat. p. 53) with Agrus kandiensis; they have, since an acquaintance with a larger series of specimens, been considered as distinct, and described by M. H. Deyrolle in the Ann. Soc. Ent. Belg. (vide ante, p. 62) under the names of Agus ogivus and Agus philippinensis, from Malacca and the Philippines (the former is also a native of Borneo). Agus kandiensis was represented in Mr. Hope's collection by a var. minor, and was placed in his Catalogue as a synonym of Agus cicatricosus, Wiedemann; the latter now proves to be the Agus acuminatus, Fab. The following is a more extended description of $A$. kandiensis :-

๙. (var. max.) Nigro-brunneus, obscurus, parum nitidus; mandibulis robustis, arcuatis, ad medium dente obtuso instructis ; capite antice excavato, in medio tuberculo obtuso armato, lateraliter pone oculos angulatim lobato, vertice plano, lateribus utrinque fortiter et rugose punctatis; prothorace transverso, lateribus rectis, angulis anticis paulo emarginatis, posticis oblique truncatis ; elytris brevibus, nitidis, parum convexis.

The male (var. max.) is distinguished from that of $A$. philippinensis, to which this species is very closely allied, by the truncation of the posterior angles of the thorax, which are scarcely emarginate, by its more convex form in all its developments, by its coarser punctuation, and the brevity of the elytra. The female is also conspicuously shorter and more convex, with the punctuation of the 
upper surface and thorax stronger and sparser. The differences here described are clearly indicated in the somewhat extensive series of examples of both $A$. kandiensis and E.phitippinensis in my own collection, but whether they are of specific value, or merely local variation, is doubtful.

\section{Gnaphaloryx dilaticollis, Parry.}

A single of specimen was described at p. 51 of iny former Catalogue; in examining recently the Hopeian collection at Oxford, I detected an insect which I have every reason to believe is the $q$ of the same species. There being no locality stated, I can only reiterate the opinion that its habitat will prove to be the Indian Archipelago.

\section{Pseudodorcus (n. g.) hydrophiloides.}

Dorcus hydrophiloides, ơ, Hope, Cat. Lucan. p. 23.

Dorcus carbonarius, + , Westw. Tr. Ent. Soc. ser. 3, i. 515, pl. xxi. fig. 3 .

Of this interesting insect single specimens exist in the Hopeian collection at Oxford ( $\delta$ from Melville Island), in the British Museum ( $q$ ), and in my own collection (ㅇ). Having recently compared my own specimen with that in the Hopeian collection, I am fully convinced of the propriety of uniting them as the same species. I may further add, that by a typographical error, D. hydrophiloides was stated in my former Catalogue to be a $q$, whereas it is indubitably a $\delta$, and is described as such by the author.

Professor Westwood in his description of $D$. carbonarius, ㅇ (loc. cit.), fully appreciating the difficulty of properly locating the insect, concludes thus:

"The general structure of this female insect removes it generically from all the other groups with the females of which we are acquainted. The rounded prothorax and spinose tibiæ separate it from the true Lucani. In Odontolabis (Alces, etc.) the hind tibiæ are simple. In $L$. Rafflesii, nepalensis, and Chevrolatii, the form of the prothorax and broad fore-tibia of this new insect are not found. It is, however, much closer to some of the larger 
species of Dorcus, especially in the toothing of the legs, and in the produced clypeus, but its broader form and rounded thorax remove it from all of these."

I fully coincide with the author, as to this species being nearer in affinity with the Dorcidae than with either the Lucanidae, Odontolabidae, or Cladognathidee. Taking into consideration the several characters above-mentioned, and the small head and mandibles, in the only male specimen known to me, which is probably the var. max., I am induced to place this species at the head of the second division of the Dorcidce, under the generic name of Pseudodorcus.

\section{Sclerostomus tristis, Deyr., n. sp.}

"Allied to S. Bacchus, as regards size and form, but more depressed, and more opaque.

Mandibles somewhat similar, but presenting a kind of inclined plane from the external margin to the interior teeth, with a rounded tubercle in the middle of this plane in lieu of the ridge which exists in S. Bacchus.

Head nearly similar, except the post-ocular tubercles which are less developed laterally, and much more so posteriorly.

Prothorax with its sides more parallel, especially behind; its posterior angles, although likewise truncate, are much more pronounced.

Scutellum half the size of that of its congener.

Elytra flatter, more opaque, punctuation similar to that of S. Bacchus. Beneath much more opaque.

Finally, this species is distinguished by its general form, its more quadrate prothorax, its very small scutellum, and its generally more opaque aspect.

Hab.-Chili.

Coll. Mniszech."

(H. Deyrolle.)

Sclerostomus marginipennis, Deyr., n. sp.

"Allied to S. Lessonii, Buq., and Philippi, Westw.; more nearly related to the latter by the squamose lateral bands of the elytra, which reach the margin. Of the same form as S. Philippi, but a trifle smaller, and more 
parallel; the prothorax in the var. max. of the present species being scarcely perceptibly widened in front.

The punctuation is analogous, although slightly stronger and less regular, especially in the female, the general aspect also is much duller.

The squamose border of the prothorax and elytra is nearly twice as wide as in S. Philippi, and finally, the legs in the present species are always red, whilst in its congener they are black.

In short, this species is easily recognised by the following principal characters:- -form more parallel; large size; stronger punctuation; duller aspect; squamose band much wider; red legs.

Hab.-Chili.

Coll. Mniszech.”

(H. Deyrolle.)

Sclerostomus elongatus, Deyr., n. sp.

"Allied to S. Philippi, but much more elongate in proportion, and more parallel; punctuation conspicuously stronger, almost forming striæ and ridges, the latter character very apparent and well marked in the female.

Prothorax with its lateral margins quite straight from one angle to the other, very slightly widened in front, its angles prominent.

Squamose border of the prothorax and elytra analogous to that of S. Philippi, but a little narrower.

This species is especially recognisable by its elongate and parallel form.

Hab.-Chili.

Coll. Mniszech.”

(H. Deyrolle.)

\section{Sclerostonus cruentus, Burm.}

S. cruentus, o , Burm. Handb. v. 425.

S. neotragus, ठ, Westw. Tr. Ent. Soc. N. S. iii. 208, pl. xi. fig. 3.

S. ditomoides, §, Westw. loc. cit. fig. 4.

S. cribratus, + , Thoms. Cat. Luc. 429.

The insect described by Dr. Burmeister appears to have been in an abnormal condition, the rufous coloration of 
the elytra being evidently that of an immature specimen, such as I now possess, and which corresponds exactly with Dr. Burmeister's description of S. cruentus, and furthermore with that of S. neotragus, Westw. The nomenclature of this species will thus stand as above given. The same habitat, Brasil, is given in each of the several descriptions.

\section{Lissotes opacus, Deyr., n. sp.}

"Allied to L. obtusatus, Westw., a trifle smaller, more opaque; having a very distinct pruinose aspect; punctuation perceptibly finer and more regular.

Mandibles of the same form, but a little less elongate, the vacant space which they circumscribe at the base being smaller. Head a trifle more parallel, its punctuation finer and closer, armed on the middle of the forehead with two little shining tubercles, but slightly separate from each other.

Prothorax flatter, with the anterior angles more rounded.

Elytra with the pruinose appearance more pronounced, clothed with erect ferruginous hairs, sparsely dispersed on the disc but denser at the sides; this vestiture is much more apparent than in $L$. obtusatus. This species is readily distinguished by its punctuation and especially by its frontal tubercles.

Hab.-Van Diemen's Land. Coll. Mniszech."

(H. Deyrolle.)

In addition to this species, I have to enumerate the following species of Lissotes, of which drawings were exhibited by Professor Westwood at the Meeting of our Society, on the 3rd of January, 1870, and for the remarks on which here given, I am indebted to him.

No. 1. Lissotes Launcestoni, Westw., MS. Very nearly allied to L. obtusatus, but comparatively longer and more depressed.* Hab.-North of Tasmania.

No. 2. Lissotes latidens, Westw. MS. Female unknown. Hab.-Maria Island, east coast of Tasmania.

No. 3. Lissotes forcipula, Westw., MS. Allied to $L$. crenatus, Westw., in the structure of its mandibles, but

* It is the opinion of certain Entomologists that this may ultimately prove to be a mere local form of $L$. obtusatus. 
sufficiently distinct in form, not being so ovate or convex, with a much smaller head, and more strongly punctured. A single male in Coll. Parry, and another in the collection at the Jardin des Plantes. Hab.-Tasmania.

Obs. There is extant in the Oxford Museum a specimen, of which the habitat is unknown, which may prove to be the female of this species.

No. 4. Lissotes furcicornis, Howitt, MS. An excellent species, $\delta$ $\uparrow$. Mus. Oxon.; $\delta$ Mus. Parry. Hab.Mountains 60 miles N.E. of Melbourne.

No. 5. I have a specimen of a $q$ insect, from Tasmania, assimilating considerably to, but much smaller than the $q$ of $L$. crenatus, to which Prof. Westwood has assigned the MS. name of $L$. subcrenatus, but not being acquainted with the $\delta$, he does not think it advisable for the present to characterize it.

\section{Genus Lissapterus, Deyr., n. g.}

"Genus established on the Lissotes Howittanus, Westw., characterized by :-

The antennæ, which are entirely destitute of leaflets, these being represented by articulations simply flattened on the whole of their upper and lower surfaces, and of which the villose portion is limited to the extremities, a remarkable character, present only on the terminal articulation, which is straightly truncate, and, as it were, abruptly cut off at its extremity.

The anterior tibiæ, which are considerably produced beyond the insertion of the tarsi into a bidentate process, as in Anoplocnemus, and some other genera of Lucanidce.

Lastly, the monstrous head and very small eyes, the latter completely divided by the ocular canthus."

(H. Deyrolle.)

\section{Cardanus cribratus, n. sp. (ठర.)}

C. parvus, cylindricus, niger, subopacus, fortiter et grosse punctatus; mandibulis brevibus, simplicibus; capite angulis ante oculos rotundatis; prothorace disco impresso, antice tuberculato; elytris foveolato-striatis, interstitiis elevatis, planis; tibiis quatuor irregulariter tri- aut quadri-nodoso-spinosis; corpore subtus rugosopunctato. 
Hab.-Ins. Philip.

Long. $4 \frac{1}{2}$ lin. In Mus. Brit.

Considerably smaller than Cardanus sulcatus, West., but closely allied to it; the head more strongly punctured, less emarginate in front, the angles in front of the eyes rounded, instead of being rectangular as in $C$. sulcatus, the prothorax less closely punctate, the interstices of the elytra, moreover, are smooth, and the external denticulation of the tibiæ not so strong.

\section{Ceratognathus Westwoodii, Thomson.}

The 우 of this species, hitherto unknown to our collections, has recently been received at the Hopeian Museum, Oxford; it was sent by Dr. Howitt, from Melbourne, as distinct, and under the MS. name of $C$. setiger. The $q$ is readily distinguished from the $\delta$ by its very short and more strongly punctured mandibles.

\section{Ceratognathus helotoides, Thomson.}

Specimens, both $\delta$ and $q$, of this hitherto rare species have recently been received both by $\mathrm{Mr}$. Bates and myself, from the province of Canterbury, New Zealand, collected by Mr. Fereday. $C$. helotoides has, I believe erroneously, been stated as belonging to the Australian fauna.

\section{Ceratognathus abdominalis, n. sp. (우).}

C. parvulus, cylindricus, punctatissimus, brunneoobscurus ; elytris costis nonnullis obsoletioribus longitudinalibus, interstitiis irregulariter maculis cinereis notatis ; abdomine subtus rufo-piceo; tibiis posterioribus inermibus.

Hab.-Moreton Bay.

Long. corp. 5 lin.

A single specimen only has fallen under my notice; it assimilates in form and general character of sculpture to C. niger, 우, but is considerably smaller, and of an obscure brownish colour; the elytra are furnished with several small irregularly formed squamulose patches of grayish colour, of which traces are visible on the prothorax; the latter has a narrow polished longitudinal line extending 
down its centre, the antennæ are pale rufous, the clava somewhat more obscure, with the leaflets short; the abdomen is of a pitchy-red, and strongly punctate; the anterior and intermediate tibiæ are armed with a small acute spine near the centre, and the former are destitute of the internal apical tooth which is conspicuous in $C$. niger. C. abdominalis is one of the smallest species of the Lucanoid Coleoptera with which I am acquainted.

\section{Sinodendron americanum, Palisot.}

A specimen of an insect thus named, sent by Professor Agassiz, has been recently added to my collection, through the kindness of my friend Dr. Kaup of Darmstadt. On comparing it with the European species S. cylindricum, I have no reason to alter the opinion already expressed (Cat. p. 65) as to the identity of the two insects. Dr. Leconte confirms me in this view, having recently informed me that $S$. americanum has never fallen under his notice, and that he thinks it must be considered as a very questionable species.

The following eight species appeared in my Catalogue of 1864, but were then undescribed. They have since been described as follows :-

1. Lucanus laticornis, Deyr. Ann. Soc. Ent. Fr. 1864, p. 312.

2. Hexarthrius Chaudoiri, Deyr.

3. Odontolabis striatus, Deyr.

4. " nigritus (sic), Deyr.

5. , intermedius, Deyr.

6. Platycerus ebeninus, Deyr.

7. Sclerostomus signatipennis, Deyr.

8. $\quad$ " lineatus, Deyr.

$\begin{array}{ll}\Longrightarrow & \text { p. } 312, \text { pl. iv. fig. } 1 . \\ , & \text { p. } 313, \text { pl. iv. fig. } 3 . \\ , & \text { p. } 315 . \\ " & \text { p. } 315 . \\ = & \text { p. } 317, \text { pl. iv. fig. } 4 . \\ , & \text { p. } 319 . \\ , & \text { p. } 319 .\end{array}$

As to Hexarthrius Chaudoiri, vide ante, p. 56. 
The following twenty-five, appearing as species in my Catalogue of 1864, are now suppressed.

1. Chiasognathus Mniszechii,

2.

Thoms.

" Blan.

3. Lamprima splendens, Erichs.

4. ,, rutilans, Erichs.

5. , , sumptuosa, Hope.

6. Lucanus Hopei, Parry.

7. , $\quad$ sericans, Voll.

8. Hexarthrius Chaudoiri, Deyr.

9. Cladognathus quadrinodosus,

10. Parry.

11. ,

, bisignatus, Parry.

12. , crenicollis, Thoms. quadridens, Hope.
13. Cyclorasis Jeketii, Parry.

14. Cyclommatus Maitlandi, Parry.

15. Eurytrachelus Bubalus, Perty.

16. ,, Thomsoni,

17. Dorcus submolaris, Hope. Parry.

18. " brevis, Say.

19. ", scaritides, Hope.

20. " carbonarius, Westw.

21. Egus lunatus, Weber.

22. , labilis, Westw.

23. Sclerostomus Lessonii,

24. ", neotragus, Buquet.

25. Westw. ditomoides, Westw.

The following changes of nomenclature are now made :Catalogue, 1864. Catalogue, 1870.

Genus 1. Cyclorasis, Thoms. = Prismognathus, Motsch. Species.

1. Neolucanus Baladeva, Hope $=$ Neolucanus lama, Oliv.

2. Cladognathus dauricus, Motsch.= Prismognathus suboneus, Motsch.

The following seven did not appear as genera in $m y$ Catalogue of 1864 :-

\section{New Genera.}

1. Pseudolucanus, Hope, Cat. Lucan. p. 30.

2. Chalcodes, Westwood, Ann. Sci. Nat. 1834, p. 118.

3. Metadorcus, Parry, ante, p. 88.

4. Pseudodorcus, Parry, ante, p. 94.

5. Lissapterus, Deyrolle, ante, p. 98.

6. Amneidus, Coquerel, Ann. Soc. Ent. Fr. 1866, p. 325.

7. Hexaphyllum, Gray, in Grif. An. Kingd. xv. 536. 


\section{New Species.}

The following fifty did not appear as species in my Catalogue of 1864 :-

1. Chiasognathus impubis, Parry, ante, p. 68.

2. " peruvianus, Waterh. Tr. Ent. Soc. 1869, p. 18, pl. iii. figs. 2,3 .

3. Streptocerus eustictus, Philippi, Stett. Ent. Zeit. 1864, p. 316.

4. Lucanus pentaphyllus, Reiche, Ann. Soc. Ent. Fr. 1853, p. 71 (olim syn.).

5. Odontolabis Duivenbodei, Deyr. Ann. Soc. Ent. Belg. 1866, p. 25, pl. i. fig. 1.

6. Neolucanus Swinhoei, Bates, Proc. Zool. Soc. 1866, p. 346, fig. 2.

7. Psalidoremus Motschulskii, Waterh. Tr. Ent. Soc. 1869, p. 16.

8. Metopodontus, n. sp. in Mus. Paris (ined.), vide ante, p. 78.

9. " $\quad$ impressus, Waterh. Tr. Ent. Soc. 1869, p. 17.

10. $\quad$ (?) torresensis, Deyr., ante, p. 80.

11. " (?) Swanzianus, Parry, ante, p. 81

12. Prosopocoilus vittatus, Deyr. Ann. Soc. Ent. Belg. 1866, p. 28, pl. i. fig. 4.

13. " $\quad$ Lorquinii, Deyr., lib. cit., p. 26, pl. i. fig. 2.

14. $" \quad$ mysticus, Parry, ante, p. 82.

15. " Archeri, Waterh. Tr. Ent. Soc. 1869, p. 13, pl. iii. fig. 1.

16. .,$\quad$ bulbosus, Hope, Cat. Lucan. p. 20 (nec Tr. Lin. Soc. xviii. 589, pl. xl. fig. 2).

17. „ dentifer, Deyr. Ann. Soc. Ent. Belg. 1866, p. 29, pl. i. fig. 5 .

18. $\quad$ (?) Sayersii, Hope, Ann. Nat. Hist.ix. 494 (olim syn.).

19. Cyclommatus Kaupii, Deyr. Ann. Soc. Ent. Belg. 1866, p. 30, pl. ii. fig. 2.

20. Eurytrachelus eurycephalus, Burm. Handb. v. 387 (olim syn.).

21. $\quad, \quad$ Alcides, Voll. Tijd. Ent. 1865, p. 150, pl. x. fig. 3.

22. " Candezii, Parry, ante, p. 90.

23. " Castelnaudii, Deyr. Ann. Soc. Ent. Belg. 1866, p. 31, pl. ii. fig. 3.

24. $\quad$ " ceramensis, Thoms. Cat. Luean. 424 (olim syn.).

25. ", mubrofemoratus, Voll. Tijd. Ent. 1865, p. 152, pl. xi. fig. $1,2$.

26. $\quad$ opacus, Waterh. Ent. Mo. Mag. vi. 208.

27. Egus Formosa, Bates, Proc. Zool. Soc. 1866, p. 347.

28. „ philippinensis, Deyr. Ann. Soc. Ent. Belg. 1866, p. 32, pl. ii. fig. 4.

29. " ogivus, Deyr. lib. cit., p. 33, pl. ii. fig. 5 . 
30. Aggus gracilis, Deyr. lib. cit., p. 34, pl. ii. fig. 6 .

31. " amictus, Deyr. lib. cit., p. 35, pl. ii. fig. 7 .

32. Gnaphaloryx miles, Voll. Tijd. Ent. 1865, p. 155, pl. xi. fig. 5.

33. $\quad$ n. sp. (ined.), vide ante, p. 78.

34. Sclerostomus tristis, Deyr., ante, p. 95.

35. " Spinola, Solier, in Gay. Hist. Chili. v. 52 (olim syn.).

36. Sclerostomus mandibularis, Solier, lib. cit., 56 , pl. xv. fig. 5 (olim syn.).

37. $\quad$ marginipennis, Deyr., ante, p. 95 .

38. " elongatus, Deyr., ante, p. 96.

39. Lissotes opacus, Deyr., ante, p. 97.

40. " Launcestoni, Westw. MS., vide ante, p. 97.

41. " latidens, Westw. MS., " p. 97.

42. " forcipula, Westw. MS., " p. 97.

43. " furcicornis, Howitt, MS., " p. 98.

44. " subcrenatus, Westw. MS., „, p. 98.

45. Nigidius formosanus, Bates, Proc. Zool. Soc. 1866, p. 347.

46. " Parryi, Bates, ", p. 347.

47. Amneidus Godefroyi, Coquerel, Ann. Soc. Ent. Fr. 1866, p. 326, pl. vii. fig. 1.

48. Cardanus cribatus, Parry, ante, p. 98.

49. Ceratognathus abdominalis, Parry, ante, p. 99.

50. ", alboguttatus, Bates, Ent. Mo. Mag. iv. 54.

I proceed to give, on the next page, a Revised Catalogue of the Lucanoid Coleoptera. 


\section{Coleoptera Pectinicornia; Div. Lucanoidea.}

For the Synonymy, see my Catalogue of 1864, Tr. Ent. Soc., 3 ser., ii. 67 .

The species marked + are known to me by description only, and those marked * are not in my collection.

Fam. I. Chiasognathidæ.

Gen. i. PHOLIDOTUS, McLeay.

Sp. 1. P. Humboldtr, Schönherr . . . . Brazil.

2. P. Sprxil, Perty . . . . . . B Bazil.

Gen. ii. CHIAsognathus, Stephens.

Sp. 1. C. Grantir, Stephens . . . Chili, Chiloe Isl.

2. C. Jousselinir, Reiche. . . . . Chili. Mniszechii, Thomson.

3. C. Latreillit, Solier . . . . . Chili.

4. C. mpubis, Parry . . . . . . Chili.

* 5. C. peruviands, C. Waterhouse . . . Peru.

Gen. iii. SPHENOGNATHUS, Buquet.

Sp. 1. S. Feisthamelir, Guérin - Colombia, New Grenada.

2. S. prionoides, Buquet . Colombia, New Grenada. albofuscus, Blanchard.

3. S. Lindenit, Murray . . . . . Peru, Quito.

4. S. Murrayi, Thomson . . . . Venezuela.

Gen. iv. DENDROBLAX, White.

Sp. 1. D. EarLII, White . . . . New Zealand.

Gen. v. RHYSSONOTUS, McLeay.

Sp. 1. R. Nebulosus, Kirby . . . . New Holland.

2. R. Jugularis, Westwood . New Holland, Melbourne.

Gen. vi. CACOSTOMUS, Newman.

Sp. 1. C. squamosus, Newman . . . . New Holland.

Gen. vii. LAMPRIMA, Latreille.

Section 1.

Sp. 1. L. Latreillii, McLeay . . . New Holland. 


\section{LAMPRIMA—continued.}

2. L. AURata, Latreille . * . . New Holland. splendens, Erichson. rutilans, Erichson.

3. L. varians, Germar . . . . New Holland.

\section{Section 2.}

4. L. Ænea, Fabricius . New Holland, Norfolk Island.

5. L. Micardi, Reiché . . New Holland, Swan River. nigricollis, Hope. sumptuosa, Hope.

Gen, viii. STREPTOCERUS, Fairmaire.

Sp. 1. S. speciosus, Fairmaire . . . . Chili. $\dagger^{*}$ 2. S. eustictus, Philippi . . . . Chili.

Gen. ix. COLOPHON, Westwood.

Sp. 1. C. Westwoodir, Gray . . . . South Africa.

* 2. C. Thunberait, Westwood . . . . Caffraria.

Fam. II. Lucanidæ.

Gen. x. MESOTOPUS, Burmeister.

Sp. 1. M. tarandus, Swederus . . . West Africa.

Gen. xi. LUCANUS, Scopoli.

Sp. 1. L. cervos, Linné . . . . . Europe.

2. L. pentaphyllus, Reiche . . . South Europe.

3. L. Turcicus, Sturm . Turkey, Greece, Asia Minor.

4. L. Laticonnis, Deyrolle . . . Smyrna, Ararat.

5. L. orientalis, Kraatz . . . Turkey, Asia Minor.

6. L. ElaphUs, Fabricius . . . North America.

7. L. Lentus, Castelnau . . . . North America.

8. L. LUNIFER, Hope . . . Himalayan India.

9. L. Mearesir, Hope . . . Himalaya, Silhet.

10. L. Cantori, Hope . . . North India, Assam.

11. L. villosus, Hope . . . . . Nepaul.

12. L. Sмrтthir, Parry . . . . East India.

13. L. Westermanni, Hope . . . . Assam.

14. L. vicinos, Hope . . . East India, Poonah.

15. L. Fortunir, Saunders . . . . China.

16. L. Maculifemoratus, Motschulsky . . Japan. Hopei, Parry.

sericans, Vollenhoven.

Gen. xii. PSEUdOLUCANUS, Hope.

Sp. 1. P. atratus, Hope

Nepaul.

2. P. capreolus, Linné . . . . North America.

* 3. P. Mazama, Leconte . . . . North Mexico.

4. P. Barbarossa, Fabricius . . Spain, North Africa. 
Gen. xiii. RHæTUS, Parry.

Sp. 1. R. Westwoodi, Parry - India, or Indian Archip.

Gen. xiv. HEXARTHRIUS, Hope.

Section 1.

Sp. 1. H. Forsteri, Hope . . . . . Assam.

2. H. Bowringir, Parry . . India, or Indian Archip.

3. H. rhinoceros, Olivier . . . Java, Sumatra. Chaudoiri, Deyrolle.

4. H. Buquetir, Hope . . . . . Java.

5. H. Mniszechil, Thomson . . . . Silhet.

Section 2.

6. H. Parryi, Hope . . . . . Silhet.

Fam. III. Odontolabidæ.

Gen. xv. ODONTOLABIS, Hope.

\section{Section 1.}

Sp. 1. O. Vollenhovir, Parry . . . . Borneo.

2. O. LudekingiI, Vollenhoven . . . Sumatra.

3. O. Wollastonit, Parry . . . . Malacea.

* 4. O. Mouнotir, Parry . . . Cambodia, Siam.

* 5. O. Lacordairir, Vollenhoven . . . Sumatra.

* 6. O. Burmeisteri, Hope . . . . . Mysore.

7. O. Delessertii, + , Guérin . . India, Neilgherries.

8. O. Cuvera, Hope . . . . Assam, Silhet. Delessertii, đo, Guérin.

9. O. gazella, Olivier . . . . Siam, China.

Section 2.

10. O. Dux, Westwood . . . . Philippine Is.

11. O. carinatus, Linné . . . India, Formosa.

12. O. Bellicosus, Castelnau . . . . Java. gracilis, Kaup.

13. O. Dalmanni, Hope - Malacea, Borneo, Sumatra.

14. O. platynotus, Hope . . . . . China.

Section 3.

15. O. Castelnaudi, Parry .

Sumatra.

* 16. O. Duivenbodir, Deyrolle

17. O. StevensiI, Thomson

Celebes.

18. O. Dejeanir, Reiche

Celebes, Sangir Is.

Malacea, Borneo. 


\section{ODONTOLABIS-continued.}

Section 4.

19. O. BICoLor, Olivier . . Malacca, Indian Archip. incequalis, Kaup.

20. O. Brookeanus, Vollenhoven . . . Borneo.

21. O. Sommeri, Parry . . . . . Manilla.

Section 5.

* 22. O. striatus, Deyrolle . . . . . Malacca.

Gen. xvi. CHALCODES, Westwood.

Sp. 1. C. cingalensis, Parry . . . . . Ceylon.

2. C. nigrita, Deyrolle . . . . . Ceylon.

* 3. C. intermedius, Deyrolle . . . . Ceylon.

4. C. eratus, Hope . . . . Tenasserim, Malacca.

Gen. xvii. HETEROCHTHES, Westwood.

Sp. 1. H. Brachypterus, Westwood . Cambodia, Siam.

Gen. xviii. NEOLUCANUS, Thomson.

Section 1.

Sp. 1. N. lama, Olivier . . . . . . Silhet.

Baladeva, Hope.

2. N. Sadndersir, Parry . . . . . East India.

3. N. nitidus, Saunders . . . . . . China.

4. N. Laticollis, Thunberg . . . . J Java.

5. N. Championi, Parry • . . . . China.

Section 2.

6. N. Swinhoei, Bates . . . . . . Formosa.

7. N. castanopterus, Hope . . . . . Nepaul.

8. N. cingulatus, Parry . . . . . . Malacea.

9. N. sinicus, Saunders . $\quad . \quad$. $\quad . \quad$. China.

\section{Fam. IV. Cladognathidæ.}

Gen. xix. CLADOGNATHUS, Burmeister.

Sp. 1. C. GIRaffa, Fabricius . . . . East India, Java.

2. C. Confucius, Hope . . . China, East India.

3. C. ? politus, Parry · China, or Indian Archip.

Gen. xx. PSALIDOREMUS, Motschulsky.

Sp. 1. P. inclinatus, Motschulsky . . . Japan.

2. P. Motschulski, C. Waterhouse . . . Japan. 
Gen. xxi. METOPODONTUS, Hope.

Section 1.

Sp. 1. M. cinnamomeus, Guérin . . . . Java.

2. M. castaneus, Hope . . . . . . India.

8. M. foveatus, Hope . . . . . . Assam.

* 4. M. (n. sp. inedit.), vide ante, p. 78 . China, Pekin.

5. M. mpressus, C. Waterhouse . . . India.

6. M. BIson, Fabricius . . . Amboyna, Celebes.

7. M. cinctus, Montrousier Woodlark Is., New Guinea.

* 8. M. ? torresensis, Deyrolle . . . Cape York.

Section 2.

9. M. Maclellandi, Hope . . . East India. quadrinodosus, Parry.

* 10. M. Jenkinsir, Westwood . . . . Assam.

\section{Section 3.}

* 11. M. Downesir, Hope . . . . Fernando Po. 12. M. SAvagiI, Hope . . . . West Africa. 13. M. ? Swanzianus, Parry. . . . West Africa.

Gen. xxii. PROSOPOCOILUS, Hope.

Section 1.

Sp. 1. P. Wallacir, Parry . . . . Halmaheira.

* 2. P. decipiens, Parry . . . . . Malabar.

3. P. Lafertei, Reiche . New Hebrides, New Caledonia.

4. P. tragulus, Vollenhoven . . . Ternate.

* 5. P. assimilis, Parry . . . . . Waigiou.

6. P. lateralis, Hope . . . . Philippine Is.

7. P. vittatus, Deyrolle . . . . Philippine Is.

8. P. Lorquinir, Deyrolle . . . . Celebes.

* 9. P. zebra, Olivier . . . . . Birmah.

10. P. flavidus, Parry . . . . East India.

Section 2.

11. P. suturalis, Olivier

Siam or Malacer.

12. P. attendatus, Parry

Malacea.

Section 3 .

13. P. Oweni, Hope

Assam.

14. P. sericeus, Westwood . Java, Borneo, Malacca.

15. P. occipitalis, Hope - Philippines, Celebes, Borneo.

16. P. biplagiatus, Westwood . Nepanl, Thibet, Siam.

17. P. ingunatus, Westwood . . . East India.

Section 4 .

18. P. Donsalis, Erichson . Philippine Is.

19. P. Perplexus, Parry

East India. 
20. P. Cavifrons, Hope . . . . Philippine Is.

21. P. approximatus, Parry . . Cochin China, Siam.

22. P. BuddHA, Hope . . . . . North India.

23. P. squamilateris, Parry . . Borneo, Malacea.

24. P. Forficula, Thomson . . . . China.

25. P. cIllpes, Thomson . . . . East India.

26. P. mysticus, Parry . . . . . Malacca.

27. P.? passaloides, Hope . . . Java, Borneo.

Section 5 .

28. P. Fonceps, Vollenhoven . . . . Sumatra.

* 29. P. Archeri, C. Waterhouse . . . North India.

30. P. Spencir, Hope . . . . . Assam.

bulbosus Hope (Tr. Linn. Soc.).

crenicollis, Thomson.

31. P. вulbosus, Hope (Cat. Lucan.) . . East India.

* 32. P. Dentifer, Deyrolle . . . East India.

33. P. curvipes, Hope . . . . East India.

\section{Section 6.}

34. P. SERricornis, Latreille Madagascar, Mozambique.

35. P. senegalensis, Klug . . Senegal, Guinea.

36. P. Antilopus, Swederus . . . West Africa. quadridens, Hope.

37. P. SAYersiI, Hope (var. præced. ?) . West Africa.

38. P. exmmus, Parry . . . . West Africa.

\section{Section 7.}

39. P. natalensis, Parry . . . . . Natal.

40. P. modestus, Parry . . . . West Africa.

41. P. Faber, Thomson . . . . West Africa.

Gen. xxiii. HOMODERUS, Parry.

Sp. 1. H. Mellyi, Parry · Guinea, Gaboon, Calabar.

Gen. xxiv. CYCLOMmatus, Parry.

\section{Section 1.}

Sp. * 1. C. Kadpir, Deyrolle . . . Batchian, Celebes.

2. C. Mniszechil, Thomson . . . . China.

3. C. metallifer, Boisduval . . Batchian, Celebes.

4. C. tarandus, Thunberg . . . . Borneo.

5. C. affinis, Parry . . . . Philippines, Borneo.

6. C. Strigiceps, Westwood . . . East India.

Section 2.

7. C. Dehaanir, Westwood . . . . Java.

8. C. insignis, Parry . . . . . Borneo.

9. C. FaUnicolor, Westwood . . . Java, Nias Is. 
Gen. xxv. PRISMOGNATHUS, Motschulsky.

Sp. 1. P. Subeneus, Motschulsky . Dauria, Pekin, Corea. dauricus, Motschulsky.

Jekelii, Parry.

2. P. subnitens, Parry . . . . East India.

3. P. platycephalus, Hope . . . . Assam.

Gen. xxvi. CANTHAROLETHRUS, Thomson.

Sp. * 1. C. Luxerir, $\delta$, Buquet . . . . Columbia.

* 2. C. ReichII, Hope ( + præced. ?) . . . Columbia.

Gen. xxvii. MACROCRATES, Burmeister.

Sp. 1. M. Bucephalus, Burmeister . . . Brazil.

Gen. xxviii. METADORCUS, Parry.

Sp. 1. M. вотundatus, Parry . . . . South America.

Gen. xxix. LEPTINOPTERUS, Hope.

Section 1.

Sp. 1. L. FrYI, Parry . . . . . . Brazil.

2. L. Femoratus, Fabricius . . . . Brazil.

* 3. L. enythrocnemus, Burmeister . . . Brazil.

4. L. tibialis, Eschscholtz . . . . . Brazil.

Section 2.

5. L. V-Niger, Hope . . . . . . Brazil.

* 6. L. pulchellus, MS. Mus. Berol . . South America.

7. L. Polyodontus, Burmeister . . . Brazil.

8. L. IBEx, Bilberg . . . . . . Brazil.

9. L. melanarius, Hope . . . . . Brazil.

Fam. V. Dorcidæ.

Division I.

Gen. xxx. HEMISODORCUS, Thomson.

Sp. 1. H. nepalensis, Hope . . . . East India.

2. H. Macleatil, Hope . . . . . Assam.

3. H. gracilis, Saunders . . . . . China.

4. H. piceipennis, Westwood . . . North China.

Gen. xxxi. +SERrognathus, Motschulsky.

Sp. + 1. S. castanicolor, Motschulsky . Tsousima Is., Corea.

Gen. xxxii. DITOMODERUS, Parry.

Sp. 1. D. mirabilis, Parry . . . . . Borneo. 
Gen. xxxiii. EURYTRACHELUS, Thomson.

Section 1.

Sp. 1. E. вucephalus, Perty . . . . . Java.

Bubalus, Perty.

2. E. Titan, Boisduval - . . Indian Archipelago.

* 3. E. Alcides, Vollenhoven . . . . Sumatra.

4. E. Westermanni, Hope . . . . Silhet.

5. E. Platymelus, Saunders . . . . . China.

Section 2.

6. E. Tityus, Hope - . . . . . Silhet.

7. E. ceramensis, Thomson . . . . Ceram.

8. E. CONCOLOR, Blanchard . . . . Amboyna.

9. E. ternatensis, Thomson . . . . Moluccas.

Thomsoni, Parry.

10. E. CANdezir, Parry . . . . . Java.

Section 3.

* 11. E. eurycephalus, Burmeister . . . Java.

12. E. SAIGA, Olivier . . . India, Java, Sumatra.

13. E. CRIBRICEPS, Chevrolat . . . Philippine Is.

14. E. PURpurascens, Vollenhoven - Malacca, Sumatra.

Section 4.

15. E. Reichir, Hope . . . . . Silhet. submolaris, Hope.

16. E. Castelnaudi, Deyrolle . . . . Bengal.

17. E. vicinus, Saunders . . . . . China.

Section 5.

18. E. Niponensis, Vollenhoven . . . Japan.

* 19. E. opacus, C. Waterhouse . . . . Japan.

20. E. RUbrofemoratus, Vollenhoven . . Japan.

21. E. elegans, Parry . . . . East India.

22. E. fulvonotatus, Parry . . . East India. bisignatus, Parry.

Gen. xxxiv. † MACRODORCAS, Motschulsky.

Sp. +1 . M. Rectus, Motschulsky . . . . Japan.

† 2. M. rugipennis, Motschulsky . . . Japan.

† 3. M. striatipennis, Motschulsky . . . Japan.

† 4. M. cribellatus, Motschulsky . . . Japan.

Gen. xxxv. DORCUS, McLeay.

Section 1.

Sp. 1. D. Anteus, Hope

Assam.

Scaritides, + , Hope. 


\section{DORCUS-continued.}

Section 2.

2. D. Dehaanir, Hope

3. D. HopII, Saunders

4. D. Parri, Thomson

Section. 3.

5. D. parallelus, Burmeister . brevis, Say.

costatus, Leconte.

6. D. parallelepipedus, Linné

7. D. Musimon, Géné

8. D. Peyronis, Reiche

Section 4. (Sp. incerti generis.)

$\dagger$ 9. D. BInervis, ㅇ, Motschulsky . . . Japan.

10. D. Rudis, \&, Westwood . India, or Indian Archip.

11. D. Derelictus, + , Parry . . . . Himalaya.

Gen. xxxvi. EGUS, McLeay.

Section 1.

Sp. 1. E. Capitatus, Westwood . Malacca, Indian Archip.

2. Æ. Parallelus . . North India, P. of Wales Is. labilis, Westwood.

3. Æ. Formose, Bates . . . . Formosa.

4. Æ. Levicollis, Saunders . . . . China.

5. Æ. EschscholtziI, Hope - Tenasserim, Malacea.

6. 无. ADELPHUS, Thomson . . . . Borneo.

7. E. malaccus, Thomson . . Malacea, Sumatra.

8. Æ. MYrmidon, Thomson - Mount Ophir, Sumatra.

9. Æ. Amictus, Deyrolle . . . . . Malacea.

10. Æ. Glaber, Parry . . . . New Guinea.

Section 2.

11. 五. platyodon, Parry . . . . . Gilolo.

12. E. INSIPIDUs, Thomson . . . . Celebes.

13. E. Blandus, Parry - . Salwatty, New Guinea.

14. Æ. PUnctipennis, Parry . . . . Borneo.

15. E. Serratus, Parry . . . . . Morty.

* 16. E. gracilis, Deyrolle . . . . . Amboyna.

17. E. IMPREssicollis, Parry . . . . Malacca.

† 18. E. ? Inerms, Fabricius . . . . Sumatra.

† 19. Æ. ? INTERRUPtis, McLeay . . . . India.

† 20. 压. Politus, Montrousier . . . Woodlark Isl.

Section 3.

21. E. acuminatus, Fabricius Java, Sumatra. lunatus, Weber.

22. Æ. Kandiensis, Hope .

23. Æ. PHILIPPINENSIs, Deyrolle

24. Æ. ogrvos, Deyrolle

Ceylon.

25. 王. Chelifer, MeLeay Philippine Isl.

Borneo.

Cambodia, Malacea. 
Gen. xxxvii. GNAPHALORYX, Burmeister.

Sp. 1. G. taurus, Fabricius . . . . Indian Archip.

2. G. Squalidus, Hope . . . . . Java.

3. G. Dilaticollis, Parry . . . Indian Archip. ?

4. G. Miles, Vollenhoven . . . Gebeh Isl.

5. G. parvolus, Hope . . . . Philippine Isl.

* 6. G. (n. sp. inedit.) vide ante, p. 78 . . . Pekin.

7. G. velutinus, Thomson . . . East India.

8. G. CYLINDRICUS, Thomson . . . East India.

9. G. Sculptipennis, Parry . . . New Guinea.

10. G. trilobatus, Parry . . . . . Borneo.

Gen. xxxviii. ALCIMUS, Fairmaire.

Sp. 1. A. Dilatatus, Fairmaire . . . Wallis Isl.

\section{Division II.}

Gen. xxxix. PSEUDODORCUS, Parry.

Sp. 1. P. HYdrophiloides, Hope N. W. Australia, Melville Is. carbonarius, Westwood.

Gen. xl. SCLEROSTOMUS, Burmeister.

Section 1.

Sp. 1. S. Bacchus, Hope . . . . . Chili.

* 2. S. Tristis, Deyrolle . . . . . . Chili.

3. S. Femoralis, Guérin . . . . . Chili.

4. S. Spinole, Solier . . . . . Chili.

5. S. Fatrmairit, Parry . . . . . . Chili.

6. S. Rouleti, Solier . . . . . . Chili.

7. S. celatus, Blanchard . . . . Chili.

8. S. fasciatus, Germain . . . . Chili.

* 9. S. lineatus, Deyrolle . . . . . Peru.

Section 2.

10. S. plagiatus, Burmeister . . . . Brazil.

11. S. mandibularis, Solier . . . . Chili.

12. S. vittatus, Eschscholtz . . . . Chili.

Lessonii, Buquet.

13. S. Philippi, Westwood . . . . Chili.

* 14. S. marginipennis, Deyrolle . . . . Chili.

* 15. S. elongatus, Deyrolle . . . . Chili.

† 16. S. Pallidocinctus, Fairmaire . . . Chili.

Section 3.

17. S. costatus, Burmeister . . . . Brazil.

18. S. cruentus, Burmeister . . . . Brazil.

neotragus, Westwood.

ditomoides, Westwood.

* 19. S. Signatipennis, Deyrolle . . . . Brazil.

20. S. tuberculatus, Solier . . . . . Chili. 
Gen. xli. SCORTIZUS, Westwood.

Sp. 1. S. maculatus, Klug . . . . . Brazil.

2. S. cucullatus, Blanchard . . . . . Chili.

Gen. xlii. PLATYCERUS, Geoffroy.

Sp. 1. P. caraboides, Linné . . . . . Europe.

2. P. caucasicus, Parry . . . . . Caucasus.

3. P. Quercus, Weber . . . . North America.

4. P. Depressus, Leconte . . . North America.

* 5. P. oregonensis, Westwood (sp. distincta?) . Oregon.

* 6. P. cerulescens, Leconte . . . California.

* 7. P. Agassizir, Leconte . . . . California.

* 8. P. ? ebeninus, Deyrolle . . . . . Brazil.

Gen. xliii. OONOTUS, Parry.

Sp. 1. O. Adspersus, Boheman . . . . . Natal.

Gen. xliv. LISSOTES, Westwood.

Sp. 1. L. Reticulatus, Westwood . . . New Zealand.

2. L. Nove-Zealandie, Hope . . . New Zealand.

* 3. L. cancroides, Fabricius . . . Tasmania.

4. L. subtuberculatus, Westwood . . Tasmania.

5. L. curvicornis, Boisduval . . . . Victoria.

6. L. obtusatus, Westwood . New Holland, Tasmania.

7. L. Launcestoni, Westwood, MS. . . . Victoria.

* 8. L. opacus, Deyrolle . . . . . . Tasmania.

* 9. L. Latidens, Westwood, MS. . . . Tasmania.

* 10. L. crenatus, Westwood . . . New Holland.

11. L. subcrenatus, Westwood, MS. . . . Tasmania.

12. L. FURCICoRnis, Howitt, MS. . . . Melbourne.

13. L. Forcipula, Westwood, MS. . . . Tasmania.

14. L. Menalcas, Westwood . . . New Zealand.

Gen. xlv. LISSAPTERUS, Deyrolle.

Sp. 1. L. Howittanus, Westwood . . . Melbourne.

* 2. L. ? pelorides, Westwood . . . Moreton Bay.

Fam. VI. Figulidæ.

Gen. xlvi. NIGIDIUS, MeLeay.

Section 1.

Sp. 1. N. grandis, Hope . . . . . West Africa.

2. N. bUbalus, Swederus . . . . West Africa.

3. N. Delgorguir, Thomson . . . . Natal.

4. N. auriculatus, Guérin . . . West Africa. 


\section{NIGIDIUS-continued.}

+5 . N. nitidus, Thomson . . . . West Africa.

* 6. N. connutus, MeLeay . . . Cambodia, Malacea.

7. N. obesus, Parry . . . . . . Malacca.

8. N. Levicollis, Westwood . . . Philippine Is.

9. N. Forcipatus, Burmeister . . . Philippine Is.

* 10. N. formosanus, Bates . . . . . Formosa.

Section 2.

* 11. N. PARryi, Bates . . . . . . Formosa.

Section 3.

12. N. Madagascariensis, Castelnau . . Madagasear.

Gen. xlvii. AMNEIDUS, Coquerel.

Sp. 1. A. Godefroyi, Coquerel . . . Bourbon.

Gen. xlviii. AGNUS, Burmeister.

Sp. 1. A. Egenus, Burmeister . . . Mauritius.

Gen. xlix. PENICHROLUCANUS, Deyrolle.

Sp. * 1. P. copricephalus, Deyrolle . . . . Malacca.

Gen. 1. FIGULUS, McLeay.

Section 1.

Sp. + 1. F. subletris, Palisot . . . . West Africa.

2. F. anthracinus, Klug . . . . Madagascar.

3. F. nigrita, Westwood . . . . . Senegal.

4. F. LÆvipennis, Montrousier . . New Caledonia.

\section{Section 2.}

5. F. trilobus, Westwood . . . New Holland.

+ 6. F. INTEGRICOLLIS, Thomson . . . Marianne Isl.

7. F. Regularis, Westwood . . . New Holland.

8. F. SUlCICOLLIS, Hope . . . . . Port Essington.

9. F. Foveicollis, Boisduval . . South Pacific Is.

10. F. striatus, Olivier . . . . . Bourbon.

+ 11. F. confusus, Westwood . East India, Cambodia?

† 12. F. latiçolis, Thomson . . . Philippine Is.

* 13. F. subcastaneus, Westwood . . . . . Java.

14. F. Manillarum, Hope . . . . Philippine Is.

15. F. Scaritiformis, Parry . . . . Malacea.

16. F. modestus, Parry . . . . New Zealand?

17. F, lilliputanus, Westwood . . . New Holland.

+ 18. F. Fissicollis, Fairmaire. Tonga Tabou, Philippine Is.?

+ 19. F. Capensis, Thunberg - Cape of Good Hope. 
Gen. li. CARDANUS, Westwood.

Sp. 1. C. sulcatus, Westwood . . . Java, Timor.

2. C. cribratus, Parry . . . . Philippine Is.

Gen. lii. XIPHODONTUS, Westwood.

Sp. 1. X. antilope, Westwood . . . South Africa.

\section{Fam. VII. Sinodendridæ.}

Gen. liii. SINODENDRON, Hellwig.

Sp. 1. S. cylindricum, Linné . . . . Europe.

2. S. Rugosum, Mannerheim . . . . Oregon.

† 3. S. americandm, Palisot (var. sp. 1, ?) North America.

\section{Fam. VII. Æsalidæ.}

Gen. liv. ÆSALUS, Fabricius.

Sp. 1. E. sCarabeloides, Fabricius . . . . Europe.

Gen. lv. CERATOGNATHUS, Westwood.

Sp. 1. C. Niger, Westwood . . New Holland, Tasmania.

2. C. mentiferus, Westwood . . Goulburn River.

3. C. Westwoodir, Thomson . . . Melbourne.

4. C. Helotoides, Thomson . . . . New Zealand.

5. C. abdominalis, Parry . . . . Moreton Bay.

Gen. Ivi. MITOPHYLLUS, Parry.

Sp. 1. M. Irroratus, Parry . . . . New Zealand.

2. M. Parrianus, Westwood . . . New Zealand.

3. M. ? alboguttatus, Bates . . . New Zealand.

Gen. Ivii. CERUCHUS, McLeay.

Sp. 1. C. tenebriondes, Fabricius . . . . Europe.

2. C. piceUs, Weber . . . . North America.

3. C. striatus, Leconte . . Oregon, Vancouver's Isl.

\section{Fam. IX. Syndesidæ.}

Gen. Iviii. SYNDESUS, McLeay,

Sp. 1. S. cornutus, MeLeay . . . . New Holland.

2. S. cancellatus, Montrousier . . New Caledonia.

Gen. lix. HEXAPHYLLUM, Gray.

Sp. 1. H. Brasiliense, Gray . . . . . Brazil.

2. H. equinoctiale, Buquet . . . New Granada. 
Summary.

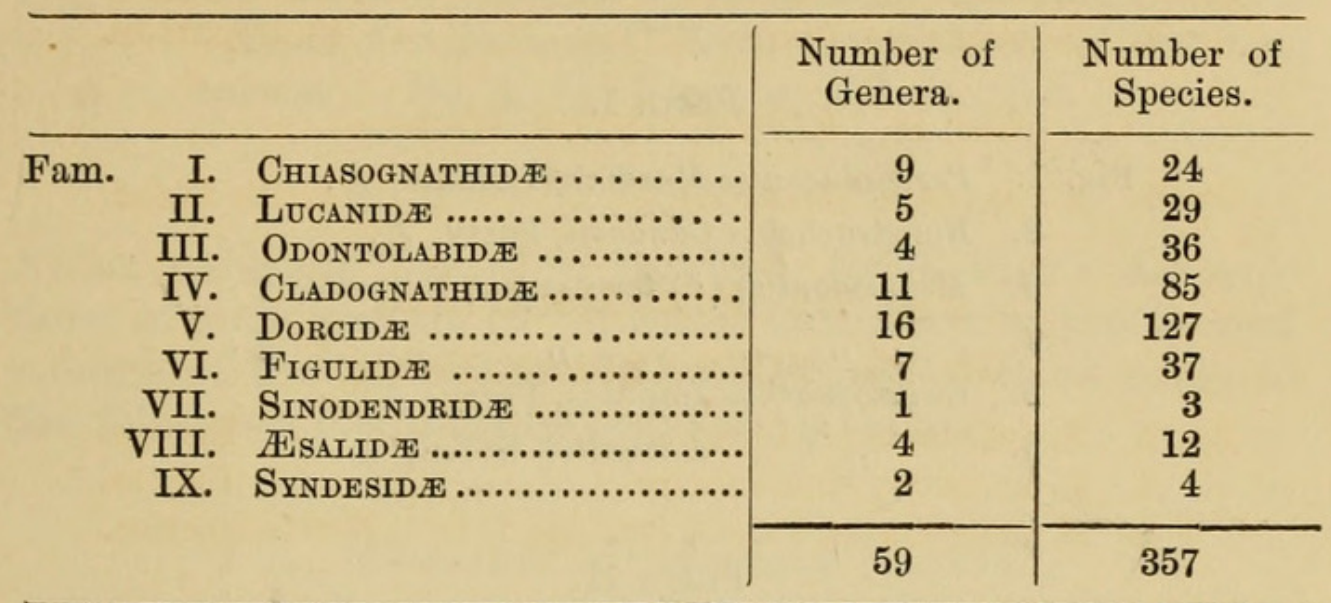

1. Chiasognathidr.

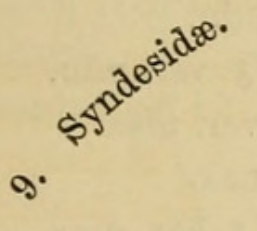

Genera 59.
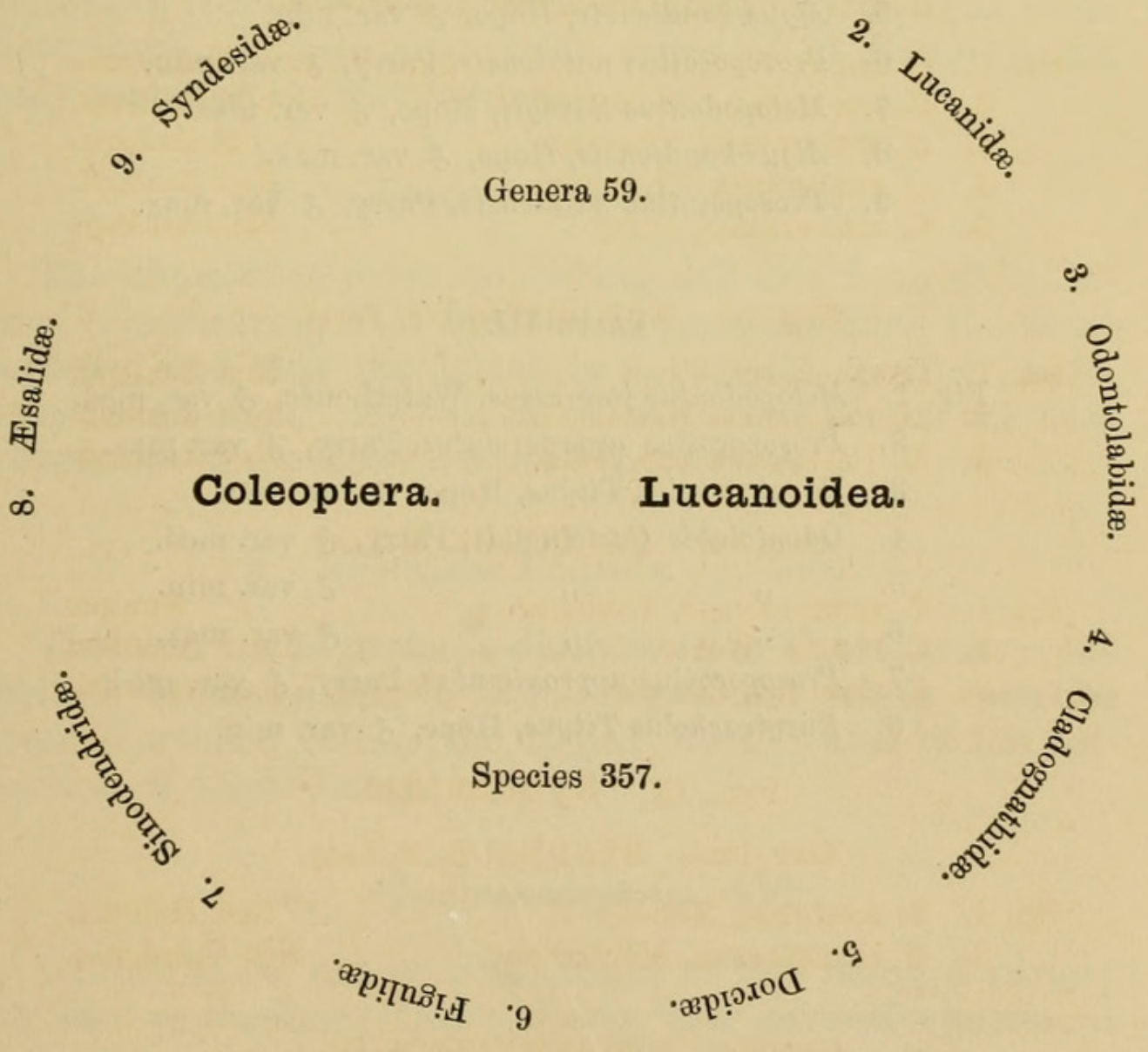
Explanation of the Plates.

\section{Plate I.}

Fig. 1. Pseudolucanus Mazama, Leconte, $\delta$.

2. Eurytrachelus Cándezii, Parry, ठ .

3. Metopodontus (?) torresensis, Deyrolle, + .

$4 . \quad, \quad$ o.

5. Chiasognathus impubis, Parry, $\delta$.

6. , $\quad$ Latreillii, Solier, o .

\section{Plate II.}

Fig. 1. Prosopocoilus Spencii, Hope, $\delta$.

2. Metopodontus (?) Swanzianus, Parry, ơ.

3. Dorcus (?) derelictus, Parry, ․

4. Metopodontus Savagii, Hope, ठठ var. min.

5. Egus kandiensis, Hope, $\delta$ var. min.

6. Prosopocoilus natalensis, Parry, ơ var. min.

7. Metopodontus Savagii, Hope, of var. max.

8. Egus kandiensis, Hope, ơ var. max.

9. Prosopocoilus natalensis, Parry, of var. max.

Plate III.

Fig. 1. Metopodontus impressus, Waterhouse, of var. med.

2. Prosopocoilus approximatus, Parry, ô var. max.

3. Eurytrachelus Tityus, Hope, ơ var. max.

4. Odontolabis Castelnaudi, Parry, ơ var. med.

5. , ,,$\quad$ o var. min.

6. ",$\quad$ के var. $\max$.

7. Prosopocoilus approximatus, Parry, of var. med.

8. Eurytrachelus Tityus, Hope, ठ var. min. 


\section{$2 \mathrm{BHL}$ Biodiversity Heritage Library}

Parry, Frederic John Sidney. 1870. "V. A Revised Cata1ogue of the Lucanoid Coleoptera; with Remarks on the Nomenclature, and Descriptions of New Species." Transactions of the Entomological Society of London 18, 53-118. https://doi.org/10.1111/j.1365-2311.1870.tb01865.x.

View This Item Online: $\underline{\text { https://www.biodiversitylibrary.org/item/51073 }}$

DOI: https://doi.org/10.1111/j.1365-2311.1870.tb01865.x

Permalink: https://www.biodiversitylibrary.org/partpdf/10202

\section{Holding Institution}

Smithsonian Libraries

\section{Sponsored by}

Smithsonian

\section{Copyright \& Reuse}

Copyright Status: Public domain. The BHL considers that this work is no longer under copyright protection.

This document was created from content at the Biodiversity Heritage Library, the world's largest open access digital library for biodiversity literature and archives. Visit BHL at https://www.biodiversitylibrary.org. 